Review

\title{
Hydrogen Sulfide in Physiology and Diseases of the Digestive Tract
}

\section{Sudha B. Singh ${ }^{1,2}$ and Henry C. Lin ${ }^{1, *}$}

1 Section of Gastroenterology, Medicine Service, New Mexico VA Health Care System, Albuquerque, NM 87108, USA; E-Mail: sbsingh14@salud.unm.edu

2 Division of Gastroenterology and Hepatology, Department of Medicine, the University of New Mexico, Albuquerque, NM 87131, USA

* Author to whom correspondence should be addressed; E-Mail: helin@salud.unm.edu; Tel.: +1-505-265-1711 (ext. 4511, 4552).

Academic Editor: Carl Gordon Johnston

Received: 1 September 2015 / Accepted: 4 November 2015 / Published: 12 November 2015

\begin{abstract}
Hydrogen sulfide $\left(\mathrm{H}_{2} \mathrm{~S}\right)$ is a Janus-faced molecule. On one hand, several toxic functions have been attributed to $\mathrm{H}_{2} \mathrm{~S}$ and exposure to high levels of this gas is extremely hazardous to health. On the other hand, $\mathrm{H}_{2} \mathrm{~S}$ delivery based clinical therapies are being developed to combat inflammation, visceral pain, oxidative stress related tissue injury, thrombosis and cancer. Since its discovery, $\mathrm{H}_{2} \mathrm{~S}$ has been found to have pleiotropic effects on physiology and health. $\mathrm{H}_{2} \mathrm{~S}$ is a gasotransmitter that exerts its effect on different systems, such as gastrointestinal, neuronal, cardiovascular, respiratory, renal, and hepatic systems. In the gastrointestinal tract, in addition to $\mathrm{H}_{2} \mathrm{~S}$ production by mammalian cystathionine- $\beta$-synthase (CBS), cystathionine- $\gamma$-lyase (CSE), $\mathrm{H}_{2} \mathrm{~S}$ is also generated by the metabolic activity of resident gut microbes, mainly by colonic Sulfate-Reducing Bacteria (SRB) via a dissimilatory sulfate reduction (DSR) pathway. In the gut, $\mathrm{H}_{2} \mathrm{~S}$ regulates functions such as inflammation, ischemia/ reperfusion injury and motility. $\mathrm{H}_{2} \mathrm{~S}$ derived from gut microbes has been found to be associated with gastrointestinal disorders such as ulcerative colitis, Crohn's disease and irritable bowel syndrome. This underscores the importance of gut microbes and their production of $\mathrm{H}_{2} \mathrm{~S}$ on host physiology and pathophysiology.
\end{abstract}


Keywords: Hydrogen sulfide; gastrointestinal tract; inflammation; Ischemia/reperfusion injury; motility; sulfate reducing bacteria; Desulfovibrio

\section{Introduction}

$\mathrm{H}_{2} \mathrm{~S}$ is a notoriously toxic gas. Exposure to $>700 \mathrm{ppm}$ can cause sudden death. Occupational Safety and Health Administration (OSHA) exposure limit is 20 parts per million (ppm). Accidents and deaths following exposure to high concentrations of $\mathrm{H}_{2} \mathrm{~S}$ have been documented [1-4]. Numerous reports have identified respiratory, cardiovascular, metabolic, neurological outcomes as a result of exposure to high levels of $\mathrm{H}_{2} \mathrm{~S}$. The most common sources of $\mathrm{H}_{2} \mathrm{~S}$ include crude petroleum, hot springs, putrefying water and sewage plants. This gas is also produced by both vertebrates and invertebrates, in addition to prokaryotes and plants. Despite its lethal effects, $\mathrm{H}_{2} \mathrm{~S}$ is a vital molecule for living organisms including humans. Abundant experimental evidences exist that indicate a role of $\mathrm{H}_{2} \mathrm{~S}$ in physiology and pathophysiology. Many excellent reviews have discussed the biological roles of $\mathrm{H}_{2} \mathrm{~S}$ with several focusing on its role in the gastrointestinal tract [5-9]. $\mathrm{H}_{2} \mathrm{~S}$ is considered the third gasotransmitter, in addition to nitric oxide (NO) and carbon monoxide (CO), and is involved in inflammation, gut motility, oxidative stress, ulcer healing, vascular tone, neuromodulation, cryoprotection, memory formation, hormone secretion, apoptosis and many other vital biologic functions. Some of these processes are also targets for $\mathrm{CO}$ and $\mathrm{NO}$ although the mechanism of actions of these other gaseous signaling molecules may be different [10,11].

Based on its role in a wide range of organ systems, novel therapies are being attempted that aim at either suppressing $\mathrm{H}_{2} \mathrm{~S}$ production or enhancing its availability [12]. $\mathrm{H}_{2} \mathrm{~S}$ is found in many tissues, including the gastrointestinal (GI) tract, which is a major site of $\mathrm{H}_{2} \mathrm{~S}$ production. $\mathrm{H}_{2} \mathrm{~S}$ in the GI tract is produced not only by the enzymes CBS [13] and CSE [14] of the host but also by sulfate-reducing bacteria (SRB) that are resident microbes using the fermentation by-product hydrogen as the substrate. Normally, the production of this toxic gas is primarily compartmentalized to the colon since the majority of the gut microbial community is compartmentalized to the distal end of the gastrointestinal tract [15]. Recent progress in the studies of physiological function of $\mathrm{H}_{2} \mathrm{~S}$ in the gut, with a special emphasis on bacteria-derived $\mathrm{H}_{2} \mathrm{~S}$ is discussed in this review.

\section{Sources of $\mathrm{H}_{2} \mathrm{~S}$}

\subsection{Mammalian $\mathrm{H}_{2} \mathrm{~S}$}

Endogenous $\mathrm{H}_{2} \mathrm{~S}$ is found in various tissues such as central nervous system, liver, kidney, cardiovascular system, lungs and gastrointestinal tract. $\mathrm{H}_{2} \mathrm{~S}$ is generated enzymatically through the reverse transsulfuration pathway by the activity of cystathionine- $\beta$-synthase (CBS), cystathionine- $\gamma$-lyase (CSE), and 3-mercaptopyruvate sulfurtransferase (3MST) [16-18] (Figure 1). Non-enzymatic pathways of $\mathrm{H}_{2} \mathrm{~S}$ generation exist and reduce elemental sulfur to $\mathrm{H}_{2} \mathrm{~S}$ [19]. However, these pathways only account for a small quantity of $\mathrm{H}_{2} \mathrm{~S}$ produced in the mammalian tissues. CBS and CSE produce 
$\mathrm{H}_{2} \mathrm{~S}$ using L-cysteine and homocysteine as substrates. 3-MST does so via the intermediate synthesis of 3-mercaptopyruvate, which is produced by cysteine aminotranferase (CAT) using cysteine as a substrate.

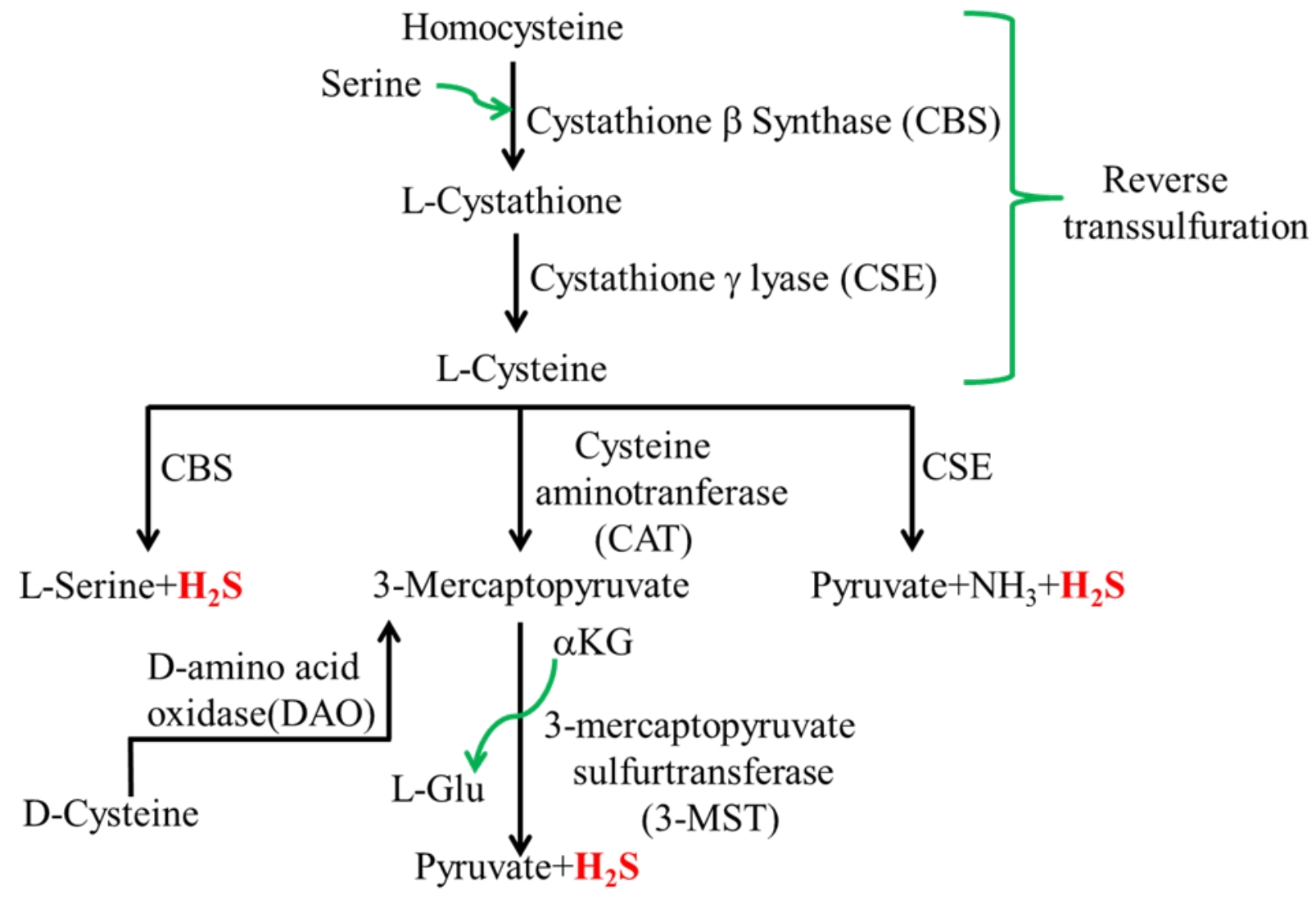

Figure 1. Biosynthesis of $\mathrm{H}_{2} \mathrm{~S}$ by mammalian cells.

A fourth pathway also exist that utilizes D-Cysteine as a substrate and involves enzymes D-amino oxidase and 3-mercaptopyruvate sulfurtransferase specifically in the cerebellum and kidney [20]. CBS and CSE are found in the cytosol while 3-MST is found in mitochondria as well as cytosol [21]. CBS, CSE and CAT use pyridoxal 5'-phosphate (PLP) as a cofactor, whereas 3-MST uses zinc as a cofactor. CBS and CSE are differentially expressed in various organs, such as the liver, kidney, brain, intestine, heart, lung [22-24], and in various cell types, such as interstitial cells of Cajal (ICC), enteric neurons [25] and smooth muscle cells [26]. By and large, CBS is predominant in the nervous system and CSE in the cardiovascular system. MST has been detected in hippocampal pyramidal neurons [16] cardiomyocytes, glial cells, kidney cells, liver cells and vascular smooth muscle cells [21,27].

\subsection{Intestinal $\mathrm{H}_{2} \mathrm{~S}$ Production by Resident Microbes}

$\mathrm{H}_{2} \mathrm{~S}$ in the intestine is also produced by some members of the resident gut bacterial community. Analysis of fecal $\mathrm{H}_{2} \mathrm{~S}$ revealed that $50 \%$ of fecal $\mathrm{H}_{2} \mathrm{~S}$ is derived from bacteria as evident by the dependence of only $50 \% \mathrm{H}_{2} \mathrm{~S}$ synthesis on pyridoxal 5'-phosphate(P-5-P) and that in germ free mice, fecal $\mathrm{H}_{2} \mathrm{~S}$ synthesis is only $50 \%$ of that in observed in colonized mice [28].

Microbial communities are an integral part of human gastrointestinal tract and carry out vital functions such as digestion, production of vitamins and other nutrients, resistance to colonization by invading pathogens and mucosal immunity [29,30]. Bacterial fermentation of complex carbohydrates 
in the colon releases large amounts of hydrogen, which is consumed by hydrogenotrophs that include methanogens, acetogens or sulfate-reducing bacteria, which produce methane, acetate, or $\mathrm{H}_{2} \mathrm{~S}$, respectively. Methanogens and SRB compete for $\mathrm{H}_{2}$ and, thus, usually one of these hydrogenotrophs predominates in the large intestine. When methanogenesis is the dominant pathway for handling fermentation derived $\mathrm{H}_{2}$, methane appears in the exhaled breath (methane excretor).

Among the most prominent producers of $\mathrm{H}_{2} \mathrm{~S}$ are sulfate-reducing bacteria (SRB) [31,32]. On the basis of the prevalence of methane excretors, sulfate reduction is the dominant hydrogenotrophic pathway in $\sim 60 \%$ of humans. Enumeration of SRB by culture dependent methods revealed a range of $10^{3}-10^{11}$ bacteria per gm of human feces [33]. SRB belong to the class $\delta$-Proteobacteria and produce $\mathrm{H}_{2} \mathrm{~S}$ using the enzyme complex dissimilatory sulfite reductases (DSR) (Figure 2). The most predominant genus in this category is Desulfovibrio, which utilize lactate and hydrogen as substrate. Other genera being Desulfobacter, Desulfomonas, Desulfobulbus, and Desulfotomaculum. The SRB use sulfate as a terminal electron acceptor for respiration, with the concomitant production of $\mathrm{H}_{2} \mathrm{~S}$ [15]. Other bacterial species belonging to different genera, such as Streptococcus, Fusobacterium, Salmonella, Enterobacter, and Helicobacter also produce $\mathrm{H}_{2} \mathrm{~S}$ from L-cysteine, by the activity of cysteine desulfhydrase [34-38]. An excellent review by Carbonero, et al. summarizes microbial pathways of sulfur metabolism in the colon [39].

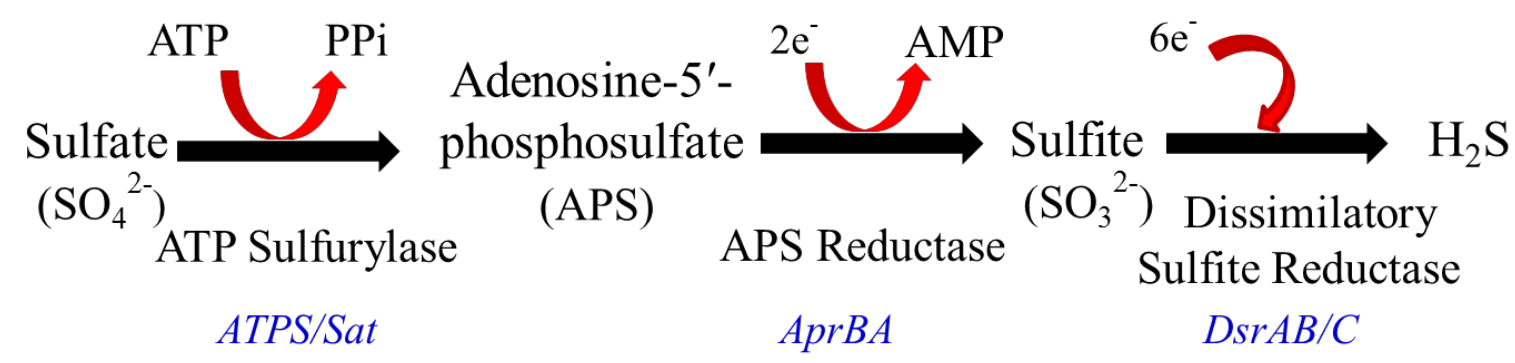

Figure 2. Dissimilatory sulfate reduction by SRB. Sulfate is activated to adenosine-5-phosphosulfate (APS) by ATP sulfurylase (ATPS), also known as sulfate adenylyltransferase (Sat). The second enzyme, APS reductase (Apr), converts APS to sulfite, which is reduced to sulfide by dissimilatory sulfite reductase (Dsr).

Colonic bacteria are responsible for generating vast quantities of $\mathrm{H}_{2} \mathrm{~S}$. Up to $1000 \mathrm{ppm}$ of $\mathrm{H}_{2} \mathrm{~S}$ has been detected in the rat cecum [40]. Analysis of flatus composition of human subjects revealed $\mathrm{H}_{2} \mathrm{~S}$ concentration in the range of 0.2 to $30 \mathrm{ppm}$ [41]. A high level of $\mathrm{H}_{2} \mathrm{~S}$ induces DNA damage, inhibits cytochrome c oxidase, and inhibits butyrate oxidation. Weisiger et al. reported comparable thiol S-methyltransferase activity in colonic mucosa and liver [42] where methylation of $\mathrm{H}_{2} \mathrm{~S}$ was the suggested mechanism for detoxification of $\mathrm{H}_{2} \mathrm{~S}$. The rate of methylation of $\mathrm{H}_{2} \mathrm{~S}$ was found to be much lower $\left(10^{-13} \mathrm{~mol} / \mathrm{min}\right.$ per milligram) and could not account for the rapid detoxification of $\mathrm{H}_{2} \mathrm{~S}$. Moreover, metabolism of $\mathrm{H}_{2} \mathrm{~S}$ was found to be unresponsive to $S$-adenosyl-L-homocysteine, an inhibitor of S-methyltransferases [43]. Later, it was found that oxidation of $\mathrm{H}_{2} \mathrm{~S}$ to thiosulfate was an efficient mechanism by which colonic mucosa dispose off this toxic gas [44]. It was observed that $\mathrm{H}_{2} \mathrm{~S}$ was metabolized to thiosulfate by cecal and right colonic mucosa at a rate that was about twenty times 
greater than that of the gastric or small bowel mucosa and eight times greater than that of the liver [41]. $\mathrm{H}_{2} \mathrm{~S}$ is also excreted out as flatus or in feces.

\section{Impact of SRB, Bacterial Derived $\mathrm{H}_{2} \mathrm{~S}$ and Lipopolysaccharide (LPS) on Host}

\subsection{SRB and Inflammatory Diseases}

Gut microbes control many aspects of human physiology and are key players in health and disease. An imbalance in the number or composition of gut microbes (dysbiosis), which can be triggered by disruptors such as antibiotics, stress, Western diet and infection, has been linked to a plethora of diseases such as obesity [45], Inflammatory bowel disease (IBD) [46], Irritable bowel syndrome (IBS) [47,48], cardiovascular diseases [49], type 2 diabetes [50] and cancer [51]. Dysbiosis tips the delicate microbial balance and often accompanies intestinal inflammation. This altered environment may promote opportunistic growth of Gram-negative members of families Enterobacteriaceae and Desulfovibrionaceae. Moreover bacteria, such as SRB, are resistant to broad spectrum antibiotics [52] as bacterial $\mathrm{H}_{2} \mathrm{~S}$ is a defense mechanism against antimicrobials [53]. This characteristic of SRB may favor a bloom of these bacteria in the setting of repeated antibiotic use.

A high number of SRB have been found in patients with ulcerative colitis (UC) [54]. SRB was also observed in higher number in feces of IBD Crohn's Disease (CD and UC) patients [55]. In addition, fecal $\mathrm{H}_{2} \mathrm{~S}$ levels were reported to be greater in UC compared to controls [56,57]. Interestingly, consumption of meat and high sulfur or sulfate containing diet that could promote the production of $\mathrm{H}_{2} \mathrm{~S}$ was associated with an increased likelihood of relapse for UC patients further suggesting a role of these microbes in the pathogenesis of UC [58]. 5-aminosalicylic acid (5-ASA), an anti-inflammatory medication commonly prescribed for UC, also inhibits SRB growth and production of $\mathrm{H}_{2} \mathrm{~S}$ suggesting an additional explanation for its efficacy [59]. $\mathrm{H}_{2} \mathrm{~S}$ inhibits oxidation of $n$-butyrate in colonic epithelial cells, thus compromising barrier function by inducing an energy deficit [60]. This may explain the increase in intestinal permeability in UC [61]. These studies also suggested that SRB growth may be favored under inflammatory conditions. However, other reports show that fecal $\mathrm{H}_{2} \mathrm{~S}$ [62] and SRB [57] were not elevated in UC. Moreover, blocking bacterial $\mathrm{H}_{2} \mathrm{~S}$ by bismuth did not show an improvement in the mouse model of dextran sulfate induced colitis [63]. However, this model of chemical colitis only partially reproduce the phenotype seen in ulcerative colitis in humans.

SRB were also found to be associated with other inflammatory conditions such periodontitis [64] and increased levels of $\mathrm{H}_{2} \mathrm{~S}$ have also been detected in periodontal pockets [65]. SRB and $\mathrm{H}_{2} \mathrm{~S}$ were also found to be much higher in Pouchitis [66]. SRB were found in greater number in constipation-predominant IBS patients compared to controls [67]. Desulfovibrionaceae were also found to be higher in number in animal models of metabolic syndrome [68]. Figure 3 summarizes the association of SRB with diseases. In addition, several case studies have reported $D$. desulfuricans bacteremia under different clinical conditions [69-71]. Some studies have highlighted the effects of probiotic and prebiotic treatments on SRB population in the gut. In one report, 4 weeks of oral consumption of probiotic Lactobacillus plantarum P-8 Lp-8 treatment caused a significant reduction of Desulfovibrio genus in human volunteers [72]. In another study, mice fed with the prebiotic glycomacropeptide (GMP) 
showed a dramatic reduction in fecal load of Desulfovibrio and also reduced levels of proinflammatory cytokines IFN- $\gamma$, TNF- $\alpha$, and IL-1 $\beta$ [73].

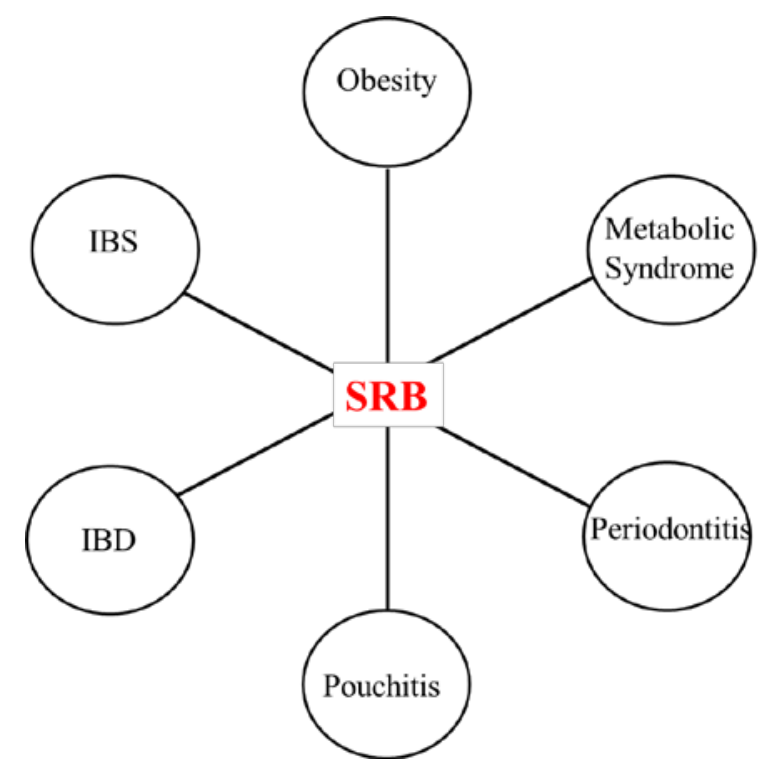

Figure 3. Association of SRB with human diseases. The evidence linking SRB with diseases is inconclusive.

In another diet-based analysis, when obese subjects were given diets to balance their gut microbes, weight loss was accompanied by a decrease in $\mathrm{H}_{2} \mathrm{~S}$-producing families Desulfovibrionaceae and Enterobacteriaceae (Escherichia, Shigella, Klebsiella, and Citrobacter), along with a decrease in proinflammatory Tumor necrosis factor (TNF- $\alpha$ ) and Interleukin (IL-6) cytokines [74]. There are conflicting reports including another study showing that Desulfovibrio levels were much lower in obese/overweight children compared to controls [75]. Thus, the role of SRB and SRB derived $\mathrm{H}_{2} \mathrm{~S}$ in the pathogenesis of a disease condition, such as obesity, remain unclear. Even as mounting evidence suggests that SRB is associated with inflammatory conditions, it is not clear whether this is an epiphenomenon or SRB are the etiological agents of the disease.

In addition to $\mathrm{SRB}$, other $\mathrm{H}_{2} \mathrm{~S}$-producing gut bacteria, such a Fusobacterium, have also been found to be associated with IBD [76]. Fusobacterium isolated from IBD patients induced inflammatory responses in colonic cell lines [77]. Genomic analysis of the colorectal carcinomas revealed the expansion of Fusobacterium on the mucosal surface of these cancers [78]. Since $\mathrm{H}_{2} \mathrm{~S}$ is a known genotoxic agent [79], it is plausible that increased $\mathrm{H}_{2} \mathrm{~S}$ production as a result of expansion of Fusobacterium may be the link between Fusobacterium and colorectal tumors. Moreover, E. coli, another $\mathrm{H}_{2} \mathrm{~S}$-producing enteric bacteria, has also been found to be associated with $\mathrm{CD}$ and colorectal cancer [80]. The connection between $\mathrm{H}_{2} \mathrm{~S}$-producing gut bacteria and inflammation was further supported by the finding that Bilophila wadsworthia, a sulfite-reducing bacteria that generates $\mathrm{H}_{2} \mathrm{~S}$ similar to Desulfovibrio was higher in concentration in mice fed with high fat diet and this was associated with proinflammatory responses in genetically susceptible mice [81].

$\mathrm{H}_{2} \mathrm{~S}$ production by these gut microbes can also lead to secondary effects including promoting the growth of pathogens. $\mathrm{H}_{2} \mathrm{~S}$ in the gut is generally detoxified to thiosulfate by the colonic mucosa. Under the conditions of inflammation, reactive oxygen species (ROS), generated by the activity of 
neutrophils, oxidize thiosulfate to tetrathionate. Salmonella is capable of readily utilizing tetrathionate as electron acceptor and this confers growth advantage for this enteric pathogen [82] in overcoming colonization resistance. Moreover, Salmonella also produces $\mathrm{H}_{2} \mathrm{~S}$ from thiosulfate [83,84]. Thus, $\mathrm{H}_{2} \mathrm{~S}$ production by these bacteria may allow positive feedback favoring growth of pathogens such as Salmonella.

\subsection{Effects of SRB Activity on Host}

What is the effect of SRB and other $\mathrm{H}_{2} \mathrm{~S}$-producing gut microbes on host physiology and pathophysiology? Are SRB beneficial or harmful? Can this information be utilized to develop novel therapies to tackle inflammatory diseases based on targeting SRB?

Studies on effect of LPS derived from SRB provide further clues about potential impact of these bacteria on the host. LPS from $D$. desulfuricans causes secretion of proinflammatory cytokine IL-6 and neutrophils, basophils, and T-cell attracting chemokine IL-8 by human gingival fibroblast (HGF-1) cell line [85] and in human umbilical vein endothelial (HUVEC) cells [86] and IL-6 by Tamm-Horsfall protein 1 (THP1) cells [87], whereas it downregulated IL-8 secretion by Colonic adenocarcinoma (Caco-2 cells) [88]. This inconsistency in these results could be due to the fact that Caco-2 cells are derived from colon, which is a natural habitat for SRB and thus may respond differently to these bacteria or its products. It would be valuable to study if Desulfovibrio-derived LPS triggers the production of mammalian or bacterial $\mathrm{H}_{2} \mathrm{~S}$. Interestingly, E.coli LPS can cause increase in plasma $\mathrm{H}_{2} \mathrm{~S}$ levels in mice along with inflammation and increased expression of CSE [89].

However, the direct impact of SRB on host physiology remains unknown. One possible way to study the unilateral effects of SRB on the host is by introducing exogenous SRB into the host. One such study was conducted by Rey et al., where gnotobiotic mice were colonized with gut bacterial species with or without Desulfovibrio piger and these mice were fed different diets [90]. High levels of cecal $\mathrm{H}_{2} \mathrm{~S}$ were observed in mice colonized with $D$. piger compared to mice without $D$. piger. In addition, there was a decrease in the host consumption of amino acids in mice inoculated with $D$. piger. Mice colonized by $D$. piger had lower mRNA levels of several Ig subclasses such as IGHM and IGHA1 and claudin-4 (a tight junction protein) but high levels of matrix metalloproteinase-7; however, there was no significant effect on the gut barrier integrity. Another study highlighted the role of SRB in the biotransformation of environmental toxicants such as bacteria-driven thiolation of arsenic that enters the gut through food contaminated with this carcinogen. This activity correlates with the production of $\mathrm{H}_{2} \mathrm{~S}$ by SRB [91].

Oral administration of bacteria into the host is a standard protocol to study the host microbe relationship and has been utilized to understand the effect of probiotics [92,93] and pathogens [94,95] in animal models. Thus, oral administration of SRB in rodents may be used as an important tool to understand the impact of SRB and its production of $\mathrm{H}_{2} \mathrm{~S}$ on physiological functions of the host.

\section{Effects of Host-Derived $\mathrm{H}_{2} \mathrm{~S}$ on the Gastrointestinal System}

Table 1 summarizes some of the commonly studied functions of $\mathrm{H}_{2} \mathrm{~S}$ in gut physiology and the diseases it is associated with. Most of the physiologic studies on $\mathrm{H}_{2} \mathrm{~S}$ have been carried out by either manipulating the endogenous mammalian source of $\mathrm{H}_{2} \mathrm{~S}$ such as CBS and CSE by gain or loss of 
function or by addition of exogenous donors of $\mathrm{H}_{2} \mathrm{~S}$, such as sodium hydrosulfide (NaHS), and slow releasing donors, such as GYY4137. Some of these functions are discussed below.

Table 1. $\mathrm{H}_{2} \mathrm{~S}$ in gut physiology and diseases.

\begin{tabular}{cc}
\hline Physiology & Disease \\
\hline Protection against I/R Injury & Inflammatory Bowel Disease \\
Inflammation (Pro-/Anti-inflammatory) & Colitis \\
Motility (Excitation/Inhibitory) & Pouchitis \\
Nociception (Pro-/Anti-nociceptive) & Periodontitis \\
Colonic Secretion & Halitosis \\
Ulcer Healing & Sepsis \\
Antioxidant & Obesity \\
Apoptosis & \\
\hline
\end{tabular}

\section{1. $\mathrm{H}_{2} \mathrm{~S}$ in Ischemia/Reperfusion Injury}

Ischemia followed by reperfusion (I/R) is a commonly occurring pathological condition that can lead to tissue and organ damage. Several clinical events are almost universally associated with some degree of I/R injury including bypass surgery, stroke, organ transplantation and myocardial infarction. Several studies have provided evidence for a protective role of $\mathrm{H}_{2} \mathrm{~S}$ in I/R injury. In the heart, both in vivo and in vitro studies using endogenous and exogenous sources of $\mathrm{H}_{2} \mathrm{~S}$ have highlighted the protective role of $\mathrm{H}_{2} \mathrm{~S}$ on myocardial I/R.[96-98] that appears to involve autophagy [99,100]. Similarly, studies have shown that $\mathrm{H}_{2} \mathrm{~S}$ protects against hepatic [101-103] renal [104-106] and brain I/R injury [107,108].

In the intestine, I/R injury can result in multiorgan failure and systemic inflammation and is associated with significant mortality and morbidity [109]. A handful of studies have confirmed the role of $\mathrm{H}_{2} \mathrm{~S}$ in I/R injury. Liu et al. demonstrated that an $\mathrm{H}_{2} \mathrm{~S}$ donor, NaHS protected rats from severe intestinal I/R injury by increasing the activity of antioxidant enzymes superoxide dismutase and peroxidase [110-113]. In another study, Pan et al. showed that NaHS protected rats from intestinal I/R injury in response to cardiac arrest followed by cardiopulmonary resuscitation (CPR). Protective effects of NaHS may be mediated through reduction of reactive oxygen species (ROS), inhibition of inflammation, apoptosis and HIF-1 $\alpha$ activation. [114]. Furthermore, $\mathrm{H}_{2} \mathrm{~S}$ protected enterocytes from hypoxia as evidenced by reduced apoptotic index [115]. $\mathrm{H}_{2} \mathrm{~S}$ protected against injury $1 \mathrm{~h}$ and $2 \mathrm{~h}$ after ischemia and preserved the crypt villi height. $\mathrm{H}_{2} \mathrm{~S}$ donor added $24 \mathrm{~h}$ prior to I/R reduced post ischemic intestinal mitochondria dysfunction and this was mediated by calcium-activated big potassium (BKCa) channels [116]. In addition, preconditioning of the small bowel with the exogenous $\mathrm{H}_{2} \mathrm{~S}$ donor NaHS inhibited leukocyte rolling (LR) and adhesion (LA) induced by I/R through a p38 MAPK-dependent mechanism [117]. Thus, protective effects of $\mathrm{H}_{2} \mathrm{~S}$ on I/R injury of different organs are mediated largely by its antioxidant, anti-inflammatory and anti-apoptotic properties. A detailed review of role of $\mathrm{H}_{2} \mathrm{~S}$ in $\mathrm{I} / \mathrm{R}$ injury is discussed in an excellent review by Wu et al. [118].

\section{2. $\mathrm{H}_{2} \mathrm{~S}$ in Intestinal Inflammation}

Reports of the role of $\mathrm{H}_{2} \mathrm{~S}$ in inflammation are, at times, diametrical. $\mathrm{H}_{2} \mathrm{~S}$ can have a pro-inflammatory or anti-inflammatory effects depending on what model system is used, the source of $\mathrm{H}_{2} \mathrm{~S}$ (exogenous 
versus endogenous), the bioavailability of $\mathrm{H}_{2} \mathrm{~S}$ (slow versus fast release $\mathrm{H}_{2} \mathrm{~S}$ donors) and the route of administration. The effects of these factors are exemplified by reports in experimental models of sepsis induced by cecal ligation and puncture (CLP). Administration of NaHS ( $\sim 5.6 \mathrm{mg} / \mathrm{kg}$ ) subcutaneously improved survival in the experimental C57BL6/J mouse model of sepsis before and after the onset of CLP, decreased TNF- $\alpha$ and IL-10 cytokine production, decreased caspase-3 activation, increased bacterial clearance and decreased expression of CHOP [119]. In contrast, in a study by Zhang et al. in Swiss mice, CLP-induced systemic inflammation was associated with increased plasma levels of $\mathrm{H}_{2} \mathrm{~S}$ and higher levels of CSE gene expression and treatment with NaHS (10mg/kg i.p.) further exacerbated the CLP-induced inflammation while administration of DL-propargylglycine (PAG; $50 \mathrm{mg} / \mathrm{kg}$ i.p.) an inhibitor of CSE, reversed these effects [120]. A follow-up study by Zhang et al. demonstrated that the pro-inflammatory effect of $\mathrm{H}_{2} \mathrm{~S}$ donor $\mathrm{NaHS}(10 \mathrm{mg} / \mathrm{kg}$ i.p.) on CLP associated sepsis depended on nuclear factor kappa B (NF-kB) activation [121]. Treatment with PAG (50 mg/kg i.p.) decreased IL-1 $\beta$, IL-6, and TNF- $\alpha$. When a higher dose of NaHS was used intraperitoneally rather than subcutaneously, a clear pro-inflammatory effect of $\mathrm{H}_{2} \mathrm{~S}$ (NaHS; $14 \mu \mathrm{mol} / \mathrm{kg}$ i.p.) could be shown in a LPS-induced model of endotoxic shock in male Swiss mice where PAG (50 mg/kg i.p.) reduced this effect [89]. Thus, it appears that dosage and route of administration of NaHS may dictate whether the effects of NaHS will be pro- (high dose, i.p.) or anti-inflammatory (low dose, subcutaneous). The proinflammatory effect mediated by $\mathrm{H}_{2} \mathrm{~S}$ may be dependent on the extracellular signal-related kinases (ERK) pathway [122]. Once again, in this study, NaHS was administered by i.p. ERK dependent pro-inflammatory effects of $\mathrm{H}_{2} \mathrm{~S}$ were also observed in human monocytic cell line U937 [123].

Another factor that may influence the beneficial versus deleterious role of $\mathrm{H}_{2} \mathrm{~S}$ in inflammation is the choice of $\mathrm{H}_{2} \mathrm{~S}$ donor, which may determine bioavailability of $\mathrm{H}_{2} \mathrm{~S}$. While many reports tested the effect of the fast releasing $\mathrm{H}_{2} \mathrm{~S}$ donor NaHS, some studies have tested the effect of $\mathrm{H}_{2} \mathrm{~S}$ using a slow releasing donor GYY4137 (morpholin-4-ium-4-methoxyphenyl (morpholino) phosphinodithioate), which has been shown to exert an anti-inflammatory action in endotoxic shock model in rats [124]. GYY4137 (50 mg/kg, i.p.) administered to rats following LPS treatment decreased the rise in plasma proinflammatory cytokines (TNF- $\alpha$, IL-1 $\beta$, IL-6) and lung myeloperoxidase activity, increased plasma concentration of the anti-inflammatory cytokine IL-10, and decreased tissue damage [124]. Anti-inflammatory effects of GYY4137 are more consistently reported across different experiments [125-127]. GYY4137 treatment may be physiologically more relevant than using NaHS as this chemical may mimic slow and sustained release of endogenous $\mathrm{H}_{2} \mathrm{~S}$ by cellular enzymes. In comparing the effects of fast releasing NaHS versus slow releasing GYY4137 on LPS treated cultured macrophages, it was found that while GYY4137 clearly and dose-dependently reduced LPS evoked expression of proinflammatory cytokines, the results with NaHS were biphasic [128]. At low concentrations, NaHS did not exhibit any effect on proinflammatory cytokines but at higher concentration, was pro-inflammatory by causing enhancement of LPS-induced expression of IL-1 $\beta$ and TNF- $\alpha$. In addition, treatment of LPS-exposed RAW 264.7 cells with GYY4137 caused a concentration-dependent inhibition of the activation of NF-kB, whereas NaHS inhibited NF-kB at high concentrations while promoting NF-kB activation at lower concentrations. This study gives additional insight into the discrepancies observed among different $\mathrm{H}_{2} \mathrm{~S}$ donors.

Several other pathways have been reported to explain the anti-inflammatory effects of $\mathrm{H}_{2} \mathrm{~S}$. $\mathrm{H}_{2} \mathrm{~S}$ showed a protective effect against IFN- $\gamma$ and TNF- $\alpha$ induced injury of epithelial barrier function in 
Caco2 cells by blocking NF-kB p65 activation [129]. $\mathrm{H}_{2} \mathrm{~S}$ also prevented NF-kB activation, apoptosis and inflammation upon ischemia/reperfusion I/R injury of the gastric epithelial cells [130]. Another study reported that IL-10 may promote $\mathrm{H}_{2} \mathrm{~S}$ synthesis in the colon which, in turn, exerts a protective effect. Specifically, IL-10 deficient mice fed a vitamin B-deficient diet had low levels of colonic $\mathrm{H}_{2} \mathrm{~S}$ and an increased level of homocysteine in the serum and exhibited severe colonic inflammation [131]. Administration of IL-10 to the IL-10-deficient mice restored colonic $\mathrm{H}_{2} \mathrm{~S}$ synthesis and significantly decreased serum homocysteine levels. $\mathrm{H}_{2} \mathrm{~S}$ donors reduced colitis and $\mathrm{H}_{2} \mathrm{~S}$ inhibitors exacerbated colitis [132,133]. 5-amino-2-hydroxy-benzoic acid 4-(5-thioxo-5H-[1,2]dithiol-3-yl)-phenyl ester hydrochloride ATB-429, a $\mathrm{H}_{2} \mathrm{~S}$ releasing drug has been shown to reduce the severity of colitis [134]. Flannigan et al. reported that protective effects of $\mathrm{H}_{2} \mathrm{~S}$ in experimental colitis are mediated via stabilization of hypoxia-inducible factor (HIF)- $1 \alpha$ and that the loss of CSE-derived $\mathrm{H}_{2} \mathrm{~S}$ production led to decreased HIF-1 $\alpha$ stabilization and exacerbation of colitis [135].

In a recent study by Motta et al., $\mathrm{H}_{2} \mathrm{~S}$ promoted resolution of colonic inflammation by facilitating microbial biofilm and mucus production. Therapeutic delivery of $\mathrm{H}_{2} \mathrm{~S}$ into a hapten-induced colitis mouse model reduced inflammation, restored the microbial biofilm, and increased the production of mucus granules [136]. One mechanism by which $\mathrm{H}_{2} \mathrm{~S}$ resolves inflammation is by reducing leukocyte migration to the site of injury [137] and by enhancing neutrophil apoptosis [138]. In addition, application of $\mathrm{H}_{2} \mathrm{~S}$ to human or murine macrophages increased chemotaxsis of macrophages and the rate of phagocytosis of the bacterium Escherichia coli which resulted in a reduction of the accumulation of inflammatory cells [139]. In addition, $\mathrm{H}_{2} \mathrm{~S}$ also promotes the activity of cyclooxygenase (COX)-2 [140], an enzyme that plays crucial role in ulcer healing and resolution of inflammation [141]. Another mechanism by which $\mathrm{H}_{2} \mathrm{~S}$ exerts its anti-inflammatory effect is by involving annexin-A1 pathway [142]. Following the onset of inflammation the L-cysteine/ $\mathrm{H}_{2} \mathrm{~S}$ pathway contributes to trigger AnxA1 mobilization, which in turn controls leukocyte trafficking. As discussed in an earlier section, $\mathrm{H}_{2} \mathrm{~S}$ protects against $\mathrm{I} / \mathrm{R}$ injury and ulcer healing via its anti-inflammatory properties. Thus, based on the existing evidence, it is tempting to assume that $\mathrm{H}_{2} \mathrm{~S}$ is generally anti-inflammatory. However, more physiologically relevant studies are needed.

\section{3. $\mathrm{H}_{2} \mathrm{~S}$ in Ulcer Healing}

Wallace and colleagues showed that gastric $\mathrm{H}_{2} \mathrm{~S}$ synthesis was increased following induction of ulcer in rat stomach [143]. Administration of L-cysteine, a precursor for $\mathrm{H}_{2} \mathrm{~S}$ synthesis, as well as exogenous $\mathrm{H}_{2} \mathrm{~S}$ donors significantly enhanced gastric ulcer healing, whereas the administration of PAG, an inhibitor of endogenous $\mathrm{H}_{2} \mathrm{~S}$ synthesis, impaired ulcer healing [143]. A recent study indicated that pretreatment with L-cysteine, vitamin $\mathrm{B}_{6}$ (a cofactor for the enzyme CBS) and NaHS protected the gastric mucosa against ethanol-induced gastric lesions [144]. This study corroborated previous findings by Medeiros et al. who demonstrated that administration of PAG reversed gastric protection induced by L-cysteine in an ethanol-induced gastric damage model [145]. However, Chávez et al., presented contradictory findings where PAG treatment conferred protection to the gastric mucosa in ethanol-induced gastric injury [146]. It is possible that the discrepancy in their results is due to the concentration (absolute versus 50\% ethanol in the other two studies) and timing of ethanol introduction following PAG (3 h in Chávez et al. versus 30 min in Medeiros et al.) and NaHS administration (2 h 
versus $30 \mathrm{~min}$ ). It is also possible that under these different settings, other $\mathrm{H}_{2} \mathrm{~S}$ independent protective pathways may come into play, such as glutathione which is also modulated by L-cysteine and NaHS [145,147]. Nevertheless, Chávez et al. did show the protective effects of L-cysteine on gastric mucosa in their model of ethanol-induced gastric injury. The protective role of $\mathrm{H}_{2} \mathrm{~S}$ on gastric ulcer may be facilitated by its anti-inflammatory effects since NaHS and L-cysteine treatment decreased gastric lesions along with a decrease in mRNA and plasma levels of IL-1 $\beta$ and TNF- $\alpha$ [148]. In another study, PAG increased gastric mucosal ulceration and the number of hemorrhage sites following gastric mucosal damage induced by I/R injury and this effect was attenuated by administration of L-cysteine via inhibition of free radical generation [149]. It was shown that $\mathrm{H}_{2} \mathrm{~S}$ degradation was decreased at the site of ulceration and that local high concentration of $\mathrm{H}_{2} \mathrm{~S}$ may be involved in the repair [150]. In a rat model of water immersion and restraint stress induced gastric ulcers, exposure to $\mathrm{H}_{2} \mathrm{~S}$ reduced gastric ulcer index and also downregulated the expression of GRP78 and caspase 12, markers of endoplasmic reticulum stress [151,152]. Administration of ACS14, a $\mathrm{H}_{2} \mathrm{~S}$-releasing derivative of aspirin, caused attenuation of gastric damage induced by aspirin. ACS14 also attenuated Aspirin-suppressed superoxide dismutase-1 (SOD-1) expression and GSH activity [153]. Nonsteroidal anti-inflammatory drugs (NSAID) and acetyl salicylic acid (ASA) decreased $\mathrm{H}_{2} \mathrm{~S}$ formation, CSE expression and induced gastric injury, increase in myeloperoxidase (MPO) and TNF- $\alpha$ [154]. Treatment with NaHS significantly reduced these effects whereas treatment with PAG exacerbated gastric injury induced by NSAID. These effects of $\mathrm{H}_{2} \mathrm{~S}$ against gastric injury were mediated through activation of $\mathrm{K}_{\mathrm{ATP}}$ channels since glibenclamide, (K $\mathrm{K}_{\mathrm{ATP}}$ channel blocker) reversed effect of $\mathrm{NaHS}$ and pinacidil (a $\mathrm{K}_{\mathrm{ATP}}$ opener) attenuated gastric mucosal injury. $\mathrm{H}_{2} \mathrm{~S}$ regulates processes such as inflammation, apoptosis, nociception and $\mathrm{I} / \mathrm{R}$ injury by activating $\mathrm{K}_{\text {ATP }}$ channels. While it is not clear how $\mathrm{H}_{2} \mathrm{~S}$ activates $\mathrm{K}_{\mathrm{ATP}}$ channels, it has been found that $\mathrm{K}_{\mathrm{ATP}}$ channel is sulfhydrated by $\mathrm{H}_{2} \mathrm{~S}$ [155] and that $\mathrm{H}_{2} \mathrm{~S}$ activated cloned rvKir6.1/rvSUR 1 channels by interacting with extracellular cysteine residues.

\section{4. $\mathrm{H}_{2} \mathrm{~S}$ in Intestinal Motility}

Experimental evidence generally supports an inhibitory role of $\mathrm{H}_{2} \mathrm{~S}$ on gastrointestinal motility [156-161]. The negative effect of $\mathrm{H}_{2} \mathrm{~S}$ in some cases is mediated through KATP channels [159,162] but in others, blocking of KATP channels did not affect $\mathrm{H}_{2} \mathrm{~S}$-induced inhibition $[158,163]$. The relaxant effect of $\mathrm{H}_{2} \mathrm{~S}$ on colonic motility has also been explained, in part, by its direct inhibition of L-type calcium channel. $\mathrm{H}_{2} \mathrm{~S}$ inhibits both L-type calcium channels and BKCa channels in smooth muscle cells of rat colon [164]. In vascular smooth muscle cells, opening of $\mathrm{K}_{\mathrm{ATP}}$ channels hyperpolarizes cell membrane and inactivates voltage-dependent L-type $\mathrm{Ca}^{2+}$ channels, leading to relaxation of smooth muscle cell and dilation of blood vessel. Recently, it was demonstrated that $\mathrm{H}_{2} \mathrm{~S}$ exerted suppressive effects on colonic contractility by decreasing neurally mediated cholinergic and tachykinergic excitatory pathways [165]. It has been previously shown that $\mathrm{H}_{2} \mathrm{~S}$ significantly reduced cholinergic mediated contractions [158,160]. In another study, NaHS inhibited the contractile activity of smooth muscle cells in rat stomach and jejunum [165]. L-cysteine, a precursor of $\mathrm{H}_{2} \mathrm{~S}$, inhibited the electrical stimulation (ES) induced contraction of mouse ileum. Contractions increased following the administration of aminooxyacetic acid, an inhibitor of CBS and CSE. The treatment with glibenclamide, 
a KaTP channel blocker, reduced both the L-cysteine response and NaHS-induced inhibition of contractions [166]. The same group later identified that inhibition of electrical field stimulation-induced contractions in ileum by L-cysteine and D,L-homocysteine was decreased by the treatment with 2-aminobicyclo [2.2.1]heptane-2-carboxylate $(\mathrm{BCH})$, an inhibitor of $\mathrm{L}$ type and $\mathrm{B}^{\circ+}$ transporter systems, thus highlighting the role of the amino acid transport system in L-cysteine regulation (via $\mathrm{H}_{2} \mathrm{~S}$ ) of motility [167].

A dual excitatory and inhibitory role of $\mathrm{H}_{2} \mathrm{~S}$ was demonstrated in smooth muscle contractility, which was dependent on the dose of NaHS. Typically at lower concentrations, NaHS stimulated the contraction while at higher doses caused relaxation. NaHS also caused a biphasic effect, early transient excitation and late long-lasting inhibition on the motility of rat duodenum jejunum, ileum and colon [168]. The excitatory effects of NaHS were mediated by TRPV1 channels since capsazepine, a TRPV1 antagonist, inhibited this effect. TRPV1 channels are known to be activated by NaHS [169,170] Glibenclamide, on the other hand, did not affect NaHS induced excitatory effect but rather inhibited NaHS-induced long-lasting inhibition on the contraction of muscle strips, indicating the role of $\mathrm{K}_{\mathrm{ATP}}$ channels.

\section{Concluding Remarks}

Over the last two decades or so, studies have uncovered many roles of $\mathrm{H}_{2} \mathrm{~S}$ in physiology and disease. $\mathrm{H}_{2} \mathrm{~S}$ has been found to have dichotomous effects (stimulatory and inhibitory) on several gastrointestinal processes such as inflammation, contractile responses, nociception, cancer and apoptosis. Thus the biological functions of $\mathrm{H}_{2} \mathrm{~S}$ remain rather confusing and controversial. However, some effects of $\mathrm{H}_{2} \mathrm{~S}$ appear to be unequivocal. $\mathrm{H}_{2} \mathrm{~S}$ has been found to be protective in several animal models of I/R injury in the gastrointestinal tract, brain, lung, kidney and heart. Experimental evidences also point towards the overall protective effects of $\mathrm{H}_{2} \mathrm{~S}$ in colitis via its anti-inflammatory properties. ATB-429, an $\mathrm{H}_{2} \mathrm{~S}$ releasing derivative of mesalamine, seems promising in the treatment of colitis. $\mathrm{H}_{2} \mathrm{~S}$ also protects against gastric injury induced by administration of NSAIDS. Similarly, several other $\mathrm{H}_{2} \mathrm{~S}$ releasing compounds are effective in cancer [171] and arthritis models [172]. Thus, although excessive $\mathrm{H}_{2} \mathrm{~S}$ may be a contributing factor in diseases, the overarching effect of $\mathrm{H}_{2} \mathrm{~S}$ appears to be beneficial.

Owing to its role in several organs systems, tissues and cells, the biological significance of $\mathrm{H}_{2} \mathrm{~S}$ has now been recognized and several $\mathrm{H}_{2} \mathrm{~S}$ releasing compounds are being tested in clinical trials for the treatment of human disorders. However, our knowledge of this important gasotransmitter is far from complete. Interestingly, the multifaceted roles of $\mathrm{H}_{2} \mathrm{~S}$ parallel those of other major gaseous signaling molecules NO and CO. All three regulatory gaseous molecules are synthesized from both the mammalian and microbial sources in the body. All three are hazardous at high concentrations but favorable at low concentrations. In fact, all three gases share many common chemical properties and exert similar biological effects albeit via different mechanisms. Moreover, $\mathrm{H}_{2} \mathrm{~S}, \mathrm{CO}$ and $\mathrm{NO}$ cross talk and stimulate or inhibit each other to regulate several physiological functions. Given several similarities between $\mathrm{H}_{2} \mathrm{~S}$, $\mathrm{CO}$ and $\mathrm{NO}$ in terms of their properties and physiological function, it may be helpful to exploit the lessons learnt from $\mathrm{NO}$ and $\mathrm{CO}$ to investigate the functions of $\mathrm{H}_{2} \mathrm{~S}$ and to gain a better understanding of its role in health and disease and to develop $\mathrm{H}_{2} \mathrm{~S}$ based therapies.

Lastly, it is important to emphasize the crucial role of gut microbes in host physiology. The impact of bacteria-derived $\mathrm{H}_{2} \mathrm{~S}$ on host physiology and pathophysiology is largely unexplored but crucial area 
of research. Much work needs to be done to identify the role of bacteria derived $\mathrm{H}_{2} \mathrm{~S}$ on host biological processes. Understanding how bacteria-derived $\mathrm{H}_{2} \mathrm{~S}$ may impact host biology can help us gain a better understanding of underlying mechanism of diseases such as IBS, IBD, and obesity.

\section{Acknowledgments}

This work is supported by VA Research, Department of Defense Congressional Directed Medical Research Program and the Winkler Bacterial Overgrowth Research Fund.

\section{Author Contributions}

Both authors contributed equally to all aspects of the manuscript including study concept and design; editing and reviewing of manuscript, critical revision of the manuscript for important intellectual content.

\section{Conflicts of Interest}

Henry Lin has intellectual property rights in the area of gut microbiome.

\section{References}

1. Kfir, H.; Rimbrot, S.; Markel, A. Toxic effects of hydrogen sulfide: Experience with three simultaneous patients. QJM 2015, doi:10.1093/qjmed/hcv108.

2. Chaturvedi, A.K.; Smith, D.R.; Canfield, D.V. A fatality caused by accidental production of hydrogen sulfide. Forensic. Sci. Int. 2001, 123, 211-214.

3. Snyder, J.W.; Safir, E.F.; Summerville, G.P.; Middleberg, R.A. Occupational fatality and persistent neurological sequelae after mass exposure to hydrogen sulfide. Am. J. Emerg. Med. 1995, 13, 199-203.

4. Yalamanchili, C.; Smith, M.D. Acute hydrogen sulfide toxicity due to sewer gas exposure. Am. J. Emerg. Med. 2008, 26, e5-e7.

5. Wang, R. Physiological implications of hydrogen sulfide: A whiff exploration that blossomed. Physiol. Rev. 2012, 92, 791-896.

6. Linden, D.R. Hydrogen sulfide signaling in the gastrointestinal tract. Antioxid. Redox Signal. 2014, 20, 818-830.

7. Chan, M.V.; Wallace, J.L. Hydrogen sulfide-based therapeutics and gastrointestinal diseases: Translating physiology to treatments. Am. J. Physiol. Gastrointest. Liver Physiol. 2013, 305, G467-G473.

8. Medani, M.; Collins, D.; Docherty, N.G.; Baird, A.W.; O’Connell, P.R.; Winter, D.C. Emerging role of hydrogen sulfide in colonic physiology and pathophysiology. Inflamm. Bowel Dis. 2011, 17, 1620-1625.

9. Cipriani, S.; Mencarelli, A. Hydrogen sulfide in gastrointestinal and liver physiopathology. Inflamm. Allergy Drug Targets 2011, 10, 92-102. 
10. Magierowski, M.; Magierowska, K.; Kwiecien, S.; Brzozowski, T. Gaseous mediators nitric oxide and hydrogen sulfide in the mechanism of gastrointestinal integrity, protection and ulcer healing. Molecules 2015, 20, 9099-9123.

11. Farrugia, G.; Szurszewski, J.H. Carbon monoxide, hydrogen sulfide, and nitric oxide as signaling molecules in the gastrointestinal tract. Gastroenterology 2014, 147, 303-313.

12. Wallace, J.L.; Wang, R. Hydrogen sulfide-based therapeutics: Exploiting a unique but ubiquitous gasotransmitter. Nat. Rev. Drug Discov. 2015, 14, 329-345.

13. Stepién, P.P.; Pieniazek, N.J. The use of the L-serine sulfhydrylase assay for the estimation of cystathionine beta-synthase. Anal. Biochem. 1973, 54, 294-249.

14. Radcliffe, B.C.; Egan, A.R. A survey of methionine adenosyltransferase and cystathionine gamma-lyase activities in ruminant tissues. Aust. J. Biol. Sci. 1974, 27, 465-471.

15. Peck, H.D. Enzymatic basis for assimilatory and dissimilatory sulfate reduction. J. Bacteriol. 1961, 82, 933-939.

16. Shibuya, N.; Tanaka, M.; Yoshida, M.; Ogasawara, Y.; Togawa, T.; Ishii, K.; Kimura, H. 3-Mercaptopyruvate sulfurtransferase produces hydrogen sulfide and bound sulfane sulfur in the brain. Antioxid. Redox Signal. 2009, 11, 703-714.

17. Stipanuk, M.H.; Beck, P.W. Characterization of the enzymic capacity for cysteine desulphhydration in liver and kidney of the rat. Biochem. J. 1982, 206, 267-277.

18. Erickson, P.F.; Maxwell, I.H.; Su, L.J.; Baumann, M.; Glode, L.M. Sequence of cDNA for rat cystathionine gamma-lyase and comparison of deduced amino acid sequence with related Escherichia coli enzymes. Biochem. J. 1990, 269, 335-340.

19. Searcy, D.G.; Lee, S.H. Sulfur reduction by human erythrocytes. J. Exp. Zool. 1998, 282, 310-322.

20. Shibuya, N.; Koike, S.; Tanaka, M.; Ishigami-Yuasa, M.; Kimura, Y.; Ogasawara, Y.; Fukui, K.; Nagahara, N.; Kimura, H. A novel pathway for the production of hydrogen sulfide from D-cysteine in mammalian cells. Nat. Commun. 2013, 4, 1366, doi:doi:10.1038/ncomms2371.

21. Nagahara, N.; Ito, T.; Kitamura, H.; Nishino, T. Tissue and subcellular distribution of mercaptopyruvate sulfurtransferase in the rat: confocal laser fluorescence and immunoelectron microscopic studies combined with biochemical analysis. Histochem. Cell Biol. 1998, 110, 243-250.

22. Martin, G.R.; McKnight, G.W.; Dicay, M.S.; Coffin, C.S.; Ferraz, J.G.P.; Wallace, J.L. Hydrogen sulphide synthesis in the rat and mouse gastrointestinal tract. Dig. Liver Dis. 2010, 42, 103-109.

23. Linden, D.R.; Sha, L.; Mazzone, A.; Stoltz, G.J.; Bernard, C.E.; Furne, J.K.; Levitt, M.D.; Farrugia, G.; Szurszewski, J.H. Production of the gaseous signal molecule hydrogen sulfide in mouse tissues. J. Neurochem. 2008, 106, 1577-1585.

24. Zhang, G.; Wang, P.; Yang, G.; Cao, Q.; Wang, R. The inhibitory role of hydrogen sulfide in airway hyperresponsiveness and inflammation in a mouse model of asthma. Am. J. Pathol. 2013, 182, 1188-1195.

25. Schicho, R.; Krueger, D.; Zeller, F.; von Weyhern, C.W.H.; Frieling, T.; Kimura, H.; Ishii, I.; de Giorgio, R.; Campi, B.; Schemann, M. Hydrogen sulfide is a novel prosecretory neuromodulator in the Guinea-pig and human colon. Gastroenterology 2006, 131, 1542-1552. 
26. Hosoki, R.; Matsuki, N.; Kimura, H. The possible role of hydrogen sulfide as an endogenous smooth muscle relaxant in synergy with nitric oxide. Biochem. Biophys. Res. Commun. 1997, 237, 527-531.

27. Shibuya, N.; Mikami, Y.; Kimura, Y.; Nagahara, N.; Kimura, H. Vascular endothelium expresses 3-mercaptopyruvate sulfurtransferase and produces hydrogen sulfide. J. Biochem. 2009, 146, 623-626.

28. Flannigan, K.L.; McCoy, K.D.; Wallace, J.L. Eukaryotic and prokaryotic contributions to colonic hydrogen sulfide synthesis. Am. J. Physiol. Gastrointest. Liver Physiol. 2011, 301, G188-G193.

29. Stevens, C.E.; Hume, I.D. Contributions of microbes in vertebrate gastrointestinal tract to production and conservation of nutrients. Physiol Rev. 1998, 78, 393-427.

30. Littman, D.R.; Pamer, E.G. Role of the commensal microbiota in normal and pathogenic host immune responses. Cell Host Microbe 2011, 10, 311-323.

31. Nava, G.M.; Carbonero, F.; Croix, J.A.; Greenberg, E.; Gaskins, H.R. Abundance and diversity of mucosa-associated hydrogenotrophic microbes in the healthy human colon. ISME J. 2012, 6, 57-70.

32. Beerens, H.; Romond, C. Sulfate-reducing anaerobic bacteria in human feces. Am. J. Clin. Nutr. 1977, 30, 1770-1776.

33. Gibson, G.R.; Macfarlane, G.T.; Cummings, J.H. Occurrence of sulphate-reducing bacteria in human faeces and the relationship of dissimilatory sulphate reduction to methanogenesis in the large gut. J. Appl. Bacteriol. 1988, 65, 103-111.

34. Claesson, R.; Edlund, M.B.; Persson, S.; Carlsson, J. Production of volatile sulfur compounds by various Fusobacterium species. Oral Microbiol. Immunol. 1990, 5, 137-142.

35. Takahashi, Y.; Yoshida, A.; Nagata, E.; Hoshino, T.; Oho, T.; Awano, S.; Takehara, T.; Ansai, T. Streptococcus anginosus L-cysteine desulfhydrase gene expression is associated with abscess formation in BALB/c mice. Mol. Oral Microbiol. 2011, 26, 221-227.

36. Lee, H.; Kho, H.-S.; Chung, J.-W.; Chung, S.-C.; Kim, Y.-K. Volatile sulfur compounds produced by Helicobacter pylori. J. Clin. Gastroenterol. 2006, 40, 421-426.

37. Metaxas, M.A.; Delwiche, E.A. The L-cysteine desulfhydrase of Escherichia coli. J. Bacteriol. 1955, 70, 735-737.

38. Kredich, N.M.; Keenan, B.S.; Foote, L.J. The purification and subunit structure of cysteine desulfhydrase from Salmonella typhimurium. J. Biol. Chem. 1972, 247, 7157-7162.

39. Carbonero, F.; Benefiel, A.C.; Alizadeh-Ghamsari, A.H.; Gaskins, H.R. Microbial pathways in colonic sulfur metabolism and links with health and disease. Front. Physiol. 2012, 3, 448, doi:10.3389/fphys.2012.00448.

40. Suarez, F.; Furne, J.; Springfield, J.; Levitt, M. Production and elimination of sulfur-containing gases in the rat colon. Am. J. Physiol. Gastrointest. Liver Physiol. 1998, 274, G727-G733.

41. Furne, J.; Springfield, J.; Koenig, T.; DeMaster, E.; Levitt, M.D. Oxidation of hydrogen sulfide and methanethiol to thiosulfate by rat tissues: A specialized function of the colonic mucosa. Biochem. Pharmacol. 2001, 62, 255-259.

42. Weisiger, R.A.; Pinkus, L.M.; Jakoby, W.B. Thiol S-methyltransferase: suggested role in detoxication of intestinal hydrogen sulfide. Biochem. Pharmacol. 1980, 29, 2885-2887. 
43. Borchardt, R.T.; Cheng, C.F. Purification and characterization of rat liver microsomal thiol methyltransferase. Biochim. Biophys. Acta 1978, 522, 340-353.

44. Levitt, M.D.; Furne, J.; Springfield, J.; Suarez, F.; DeMaster, E. Detoxification of hydrogen sulfide and methanethiol in the cecal mucosa. J. Clin. Invest. 1999, 104, 1107-1114.

45. Ley, R.E.; Turnbaugh, P.J.; Klein, S.; Gordon, J.I. Microbial ecology: Human gut microbes associated with obesity. Nature 2006, 444, 1022-1023.

46. Frank, D.N.; Amand, A.L.S.; Feldman, R.A.; Boedeker, E.C.; Harpaz, N.; Pace, N.R. Molecular-phylogenetic characterization of microbial community imbalances in human inflammatory bowel diseases. Proc. Natl. Acad. Sci. USA 2007, 104, 13780-13785.

47. Lin, H.C. Small intestinal bacterial overgrowth: A framework for understanding irritable bowel syndrome. JAMA 2004, 292, 852-858.

48. König, J.; Brummer, R.J. Alteration of the intestinal microbiota as a cause of and a potential therapeutic option in irritable bowel syndrome. Benef. Microbes 2014, 5, 247-261.

49. Lam, V.; Su, J.; Koprowski, S.; Hsu, A.; Tweddell, J.S.; Rafiee, P.; Gross, G.J.; Salzman, N.H.; Baker, J.E. Intestinal microbiota determine severity of myocardial infarction in rats. FASEB J. 2012, 26, 1727-1735.

50. Qin, J.; Li, Y.; Cai, Z.; Li, S.; Zhu, J.; Zhang, F.; Liang, S.; Zhang, W.; Guan, Y.; Shen, D.; et al. A metagenome-wide association study of gut microbiota in type 2 diabetes. Nature 2012, 490, 55-60.

51. Borges Canha, M. Role of colonic microbiota in colorectal carcinogenesis: A systematic review. Rev. Esp. Enfermedades Dig. 2015, 107, doi:10.17235/reed.2015.3830/2015.

52. Ohge, H.; Furne, J.K.; Springfield, J.; Sueda, T.; Madoff, R.D.; Levitt, M.D. The effect of antibiotics and bismuth on fecal hydrogen sulfide and sulfate-reducing bacteria in the rat. FEMS Microbiol. Lett. 2003, 228, 137-142.

53. Shatalin, K.; Shatalina, E.; Mironov, A.; Nudler, E. H2S: A universal defense against antibiotics in bacteria. Science 2011, 334, 986-990.

54. Gibson, G.R.; Cummings, J.H.; Macfarlane, G.T. Growth and activities of sulphate-reducing bacteria in gut contents of healthy subjects and patients with ulcerative colitis. FEMS Microbiol. Ecol. 1991, 9, 103-111.

55. Loubinoux, J.; Bronowicki, J.-P.; Pereira, I.A.C.; Mougenel, J.-L.; Faou, A.E. Sulfate-reducing bacteria in human feces and their association with inflammatory bowel diseases. FEMS Microbiol. Ecol. 2002, 40, 107-112.

56. Levine, J.; Ellis, C.J.; Furne, J.K.; Springfield, J.; Levitt, M.D. Fecal hydrogen sulfide production in ulcerative colitis. Am. J. Gastroenterol. 1998, 93, 83-87.

57. Pitcher, M.C. The contribution of sulphate reducing bacteria and 5-aminosalicylic acid to faecal sulphide in patients with ulcerative colitis. Gut 2000, 46, 64-72.

58. Jowett, S.L.; Seal, C.J.; Pearce, M.S.; Phillips, E.; Gregory, W.; Barton, J.R.; Welfare, M.R. Influence of dietary factors on the clinical course of ulcerative colitis: A prospective cohort study. Gut 2004, 53, 1479-1484.

59. Edmond, L.M.; Hopkins, M.J.; Magee, E.A.; Cummings, J.H. The effect of 5-aminosalicylic acid-containing drugs on sulfide production by sulfate-reducing and amino acid-fermenting bacteria. Inflamm. Bowel Dis. 2003, 9, 10-17. 
60. Roediger, W.E.; Duncan, A.; Kapaniris, O.; Millard, S. Reducing sulfur compounds of the colon impair colonocyte nutrition: implications for ulcerative colitis. Gastroenterology 1993, 104, 802-809.

61. Den Hond, E.; Hiele, M.; Evenepoel, P.; Peeters, M.; Ghoos, Y.; Rutgeerts, P. In vivo butyrate metabolism and colonic permeability in extensive ulcerative colitis. Gastroenterology 1998, 115, 584-590.

62. Moore, J.; Babidge, W.; Millard, S.; Roediger, W. Colonic luminal hydrogen sulfide is not elevated in ulcerative colitis. Dig. Dis. Sci. 1998, 43, 162-165.

63. Furne, J.K.; Suarez, F.L.; Ewing, S.L.; Springfield, J.; Levitt, M.D. Binding of hydrogen sulfide by bismuth does not prevent dextran sulfate-induced colitis in rats. Dig. Dis. Sci. 2000, 45, 1439-1443.

64. Langendijk, P.S.; Hanssen, J.T.; van der Hoeven, J.S. Sulfate-reducing bacteria in association with human periodontitis. J. Clin. Periodontol. 2000, 27, 943-950.

65. Persson, S. Hydrogen sulfide and methyl mercaptan in periodontal pockets. Oral Microbiol. Immunol. 1992, 7, 378-379.

66. Ohge, H.; Furne, J.K.; Springfield, J.; Rothenberger, D.A.; Madoff, R.D.; Levitt, M.D. Association between fecal hydrogen sulfide production and pouchitis. Dis. Colon Rectum 2005, 48, 469-475.

67. Chassard, C.; Dapoigny, M.; Scott, K.P.; Crouzet, L.; Del’homme, C.; Marquet, P.; Martin, J.C.; Pickering, G.; Ardid, D.; Eschalier, A.; et al. Functional dysbiosis within the gut microbiota of patients with constipated-irritable bowel syndrome. Aliment. Pharmacol. Ther. 2012, 35, 828-838.

68. Zhang, C.; Zhang, M.; Wang, S.; Han, R.; Cao, Y.; Hua, W.; Mao, Y.; Zhang, X.; Pang, X.; Wei, C.; et al. Interactions between gut microbiota, host genetics and diet relevant to development of metabolic syndromes in mice. ISME J. 2010, 4, 232-241.

69. Verstreken, I.; Laleman, W.; Wauters, G.; Verhaegen, J. Desulfovibrio desulfuricans bacteremia in an immunocompromised host with a liver graft and ulcerative colitis. J. Clin. Microbiol. 2012, 50, 199-201.

70. Goldstein, E.J.; Citron, D.M.; Peraino, V.A.; Cross, S.A. Desulfovibrio desulfuricans bacteremia and review of human Desulfovibrio infections. J. Clin. Microbiol. 2003, 41, 2752-2754.

71. Koyano, S.; Tatsuno, K.; Okazaki, M.; Ohkusu, K.; Sasaki, T.; Saito, R.; Okugawa, S.; Moriya, K. A Case of Liver Abscess with Desulfovibrio Desulfuricans Bacteremia. Case Rep. Infect. Dis. 2015, 2015, 1-4.

72. Wang, L.; Zhang, J.; Guo, Z.; Kwok, L.; Ma, C.; Zhang, W.; Lv, Q.; Huang, W.; Zhang, H. Effect of oral consumption of probiotic Lactobacillus planatarum P-8 on fecal microbiota, SIgA, SCFAs, and TBAs of adults of different ages. Nutrition 2014, 30, 776-783.

73. Sawin, E.A.; de Wolfe, T.J.; Aktas, B.; Stroup, B.M.; Murali, S.G.; Steele, J.L.; Ney, D.M. Glycomacropeptide is a prebiotic that reduces Desulfovibrio bacteria, increases cecal short chain fatty acids and is anti-inflammatory in mice. Am. J. Physiol. Gastrointest. Liver Physiol. 2015, 309, G590-G601.

74. Xiao, S.; Fei, N.; Pang, X.; Shen, J.; Wang, L.; Zhang, B.; Zhang, M.; Zhang, X.; Zhang, C.; $\mathrm{Li}, \mathrm{M}$; et al. A gut microbiota-targeted dietary intervention for amelioration of chronic inflammation underlying metabolic syndrome. FEMS Microbiol. Ecol. 2014, 87, 357-367. 
75. Karlsson, C.L.; Onnerfält, J.; Xu, J.; Molin, G.; Ahrné, S.; Thorngren-Jerneck, K. The microbiota of the gut in preschool children with normal and excessive body weight. Obesity 2012, 20, 2257-2261.

76. Strauss, J.; Kaplan, G.G.; Beck, P.L.; Rioux, K.; Panaccione, R.; Devinney, R.; Lynch, T.; Allen-Vercoe, E. Invasive potential of gut mucosa-derived Fusobacterium nucleatum positively correlates with IBD status of the host. Inflamm. Bowel Dis. 2011, 17, 1971-1978.

77. Dharmani, P.; Strauss, J.; Ambrose, C.; Allen-Vercoe, E.; Chadee, K. Fusobacterium nucleatum infection of colonic cells stimulates MUC2 mucin and tumor necrosis factor alpha. Infect. Immun. 2011, 79, 2597-2607.

78. Kostic, A.D.; Gevers, D.; Pedamallu, C.S.; Michaud, M.; Duke, F.; Earl, A.M.; Ojesina, A.I.; Jung, J.; Bass, A.J.; Tabernero, J.; et al. Genomic analysis identifies association of Fusobacterium with colorectal carcinoma. Genome Res. 2012, 22, 292-298.

79. Attene-Ramos, M.S.; Wagner, E.D.; Plewa, M.J.; Gaskins, H.R. Evidence that hydrogen sulfide is a genotoxic agent. Mol. Cancer Res. 2006, 4, 9-14.

80. Martin, H.M.; Campbell, B.J.; Hart, C.A.; Mpofu, C.; Nayar, M.; Singh, R.; Englyst, H.; Williams, H.F.; Rhodes, J.M. Enhanced Escherichia coli adherence and invasion in Crohn's disease and colon cancer. Gastroenterology 2004, 127, 80-93.

81. Devkota, S.; Wang, Y.; Musch, M.W.; Leone, V.; Fehlner-Peach, H.; Nadimpalli, A.; Antonopoulos, D.A.; Jabri, B.; Chang, E.B. Dietary-fat-induced taurocholic acid promotes pathobiont expansion and colitis in Il10-/- mice. Nature 2012, 487, 104-108.

82. Winter, S.E.; Thiennimitr, P.; Winter, M.G.; Butler, B.P.; Huseby, D.L.; Crawford, R.W.; Russell, J.M.; Bevins, C.L.; Adams, L.G.; Tsolis, R.M.; et al. Gut inflammation provides a respiratory electron acceptor for Salmonella. Nature 2010, 467, 426-429.

83. Barrett, E.L.; Clark, M.A. Tetrathionate reduction and production of hydrogen sulfide from thiosulfate. Microbiol. Rev. 1987, 51, 192-205.

84. Clark, M.A.; Barrett, E.L. The phs gene and hydrogen sulfide production by Salmonella typhimurium. J. Bacteriol. 1987, 169, 2391-2397.

85. Dzierzewicz, Z.; Szczerba, J.; Lodowska, J.; Wolny, D.; Gruchlik, A.; Orchel, A.; Weglarz, L. The role of Desulfovibrio desulfuricans lipopolysaccharides in modulation of periodontal inflammation through stimulation of human gingival fibroblasts. Arch. Oral Biol. 2010, 55, 515-522.

86. Weglarz, L.; Dzierzewicz, Z.; Skop, B.; Orchel, A.; Parfiniewicz, B.; Wiśniowska, B.; Swiatkowska, L.; Wilczok, T. Desulfovibrio desulfuricans lipopolysaccharides induce endothelial cell IL-6 and IL-8 secretion and E-selectin and VCAM-1 expression. Cell. Mol. Biol. Lett. 2003, 8, 991-1003.

87. Zhang-Sun, W.; Augusto, L.A.; Zhao, L.; Caroff, M. Desulfovibrio desulfuricans isolates from the gut of a single individual: Structural and biological lipid a characterization. FEBS Lett. 2015, 589, 165-171.

88. Weglarz, L.; Dzierzewicz, Z.; Orchel, A.; Szczerba, J.; Jaworska-Kik, M.; Wilczok, T. Biological activity of Desulfovibrio desulfuricans lipopolysaccharides evaluated via interleukin-8 secretion by Caco-2 cells. Scand. J. Gastroenterol. 2003, 38, 73-79. 
89. Li, L.; Bhatia, M.; Zhu, Y.Z.; Zhu, Y.C.; Ramnath, R.D.; Wang, Z.J.; Anuar, F.B.M.; Whiteman, M.; Salto-Tellez, M.; Moore, P.K. Hydrogen sulfide is a novel mediator of lipopolysaccharide-induced inflammation in the mouse. FASEB J. 2005, 19, 1196-1198.

90. Rey, F.E.; Gonzalez, M.D.; Cheng, J.; Wu, M.; Ahern, P.P.; Gordon, J.I. Metabolic niche of a prominent sulfate-reducing human gut bacterium. Proc. Natl. Acad. Sci. USA 2013, 110, 13582-13587.

91. Rubin, S.C.; Alava, P.; Zekker, I.; Laing, G.D.; van de Wiele, T. Arsenic thiolation and the role of sulfate-reducing bacteria from the human intestinal tract. Environ. Health Perspect. 2014, 122, 817-822.

92. Wang, B.; Xu, H.; Wei, H.; Zeng, Z.; Xu, F. Oral administration of Bifidobacterim bifidum for modulating microflora, acid and bile resistance, and physiological indices in mice. Can. J. Microbiol. 2015, 61, 155-163.

93. Ma, Y.; Liu, J.; Hou, J.; Dong, Y.; Lu, Y.; Jin, L.; Cao, R.; Li, T.; Wu, J. Oral administration of recombinant Lactococcus lactis expressing HSP65 and tandemly repeated P277 reduces the incidence of type I diabetes in non-obese diabetic mice. PLOS ONE 2014, 9, doi:10.1371/ journal.pone.0105701.

94. Nakajima, M.; Arimatsu, K.; Kato, T.; Matsuda, Y.; Minagawa, T.; Takahashi, N.; Ohno, H.; Yamazaki, K. Oral Administration of $P$. gingivalis induces dysbiosis of gut microbiota and impaired barrier function leading to dissemination of enterobacteria to the liver. PLOS ONE 2015, 10, doi:10.1371/journal.pone.0134234.

95. Lyte, M.; Li, W.; Opitz, N.; Gaykema, R.P.; Goehler, L.E. Induction of anxiety-like behavior in mice during the initial stages of infection with the agent of murine colonic hyperplasia Citrobacter rodentium. Physiol. Behav. 2006, 89, 350-357.

96. Meng, G.; Wang, J.; Xiao, Y.; Bai, W.; Xie, L.; Shan, L.; Moore, P.K.; Ji, Y. GYY4137 protects against myocardial ischemia and reperfusion injury by attenuating oxidative stress and apoptosis in rats. J. Biomed. Res. 2015, 29, 203-213.

97. Sun, Y.-G.; Wang, X.-Y.; Chen, X.; Shen, C.-X.; Li, Y.-G. Hydrogen sulfide improves cardiomyocytes electrical remodeling post ischemia/reperfusion injury in rats. Int. J. Clin. Exp. Pathol. 2015, 8, 474-481.

98. Sun, W.-H.; Liu, F.; Chen, Y.; Zhu, Y.-C. Hydrogen sulfide decreases the levels of ROS by inhibiting mitochondrial complex IV and increasing SOD activities in cardiomyocytes under ischemia/reperfusion. Biochem. Biophys. Res. Commun. 2012, 421, 164-169.

99. Xie, H.; Xu, Q.; Jia, J.; Ao, G.; Sun, Y.; Hu, L.; Alkayed, N.J.; Wang, C.; Cheng, J. Hydrogen sulfide protects against myocardial ischemia and reperfusion injury by activating AMP-activated protein kinase to restore autophagic flux. Biochem. Biophys. Res. Commun. 2015, 458, 632-638.

100. Jiang, H.; Xiao, J.; Kang, B.; Zhu, X.; Xin, N.; Wang, Z. PI3K/SGK1/GSK3ß signaling pathway Is involved in inhibition of autophagy in neonatal rat cardiomyocytes exposed to hypoxia/reoxygenation by hydrogen sulfide. Exp. Cell Res. 2015, doi:10.1016/j.yexcr.2015.07.005.

101. Shimada, S.; Fukai, M.; Wakayama, K.; Ishikawa, T.; Kobayashi, N.; Kimura, T.; Yamashita, K.; Kamiyama, T.; Shimamura, T.; Taketomi, A.; et al. Hydrogen sulfide augments survival signals in warm ischemia and reperfusion of the mouse liver. Surg. Today 2015, 45, 892-903. 
102. Cheng, P.; Wang, F.; Chen, K.; Shen, M.; Dai, W.; Xu, L.; Zhang, Y.; Wang, C.; Li, J.; Yang, J.; et al. Hydrogen sulfide ameliorates ischemia/reperfusion-induced hepatitis by inhibiting apoptosis and autophagy pathways. Mediators Inflamm. 2014, 2014, 935251, doi:10.1155/2014/935251.

103. Zhang, Q.; Fu, H.; Zhang, H.; Xu, F.; Zou, Z.; Liu, M.; Wang, Q.; Miao, M.; Shi, X. Hydrogen sulfide preconditioning protects rat liver against ischemia/reperfusion injury by activating Akt-GSK-3 $\beta$ signaling and inhibiting mitochondrial permeability transition. PLoS ONE 2013, 8, doi:10.1371/journal.pone.0074422.

104. Bos, E.M.; Wang, R.; Snijder, P.M.; Boersema, M.; Damman, J.; Fu, M.; Moser, J.; Hillebrands, J.-L.; Ploeg, R.J.; Yang, G.; et al. Cystathionine $\gamma$-lyase protects against renal ischemia/reperfusion by modulating oxidative stress. J. Am. Soc. Nephrol. 2013, 24, 759-770.

105. Han, S.J.; Kim, J.I.; Park, J.-W.; Park, K.M. Hydrogen sulfide accelerates the recovery of kidney tubules after renal ischemia/reperfusion injury. Nephrol. Dial. Transplant 2015, 30, 1497-1506.

106. Azizi, F.; Seifi, B.; Kadkhodaee, M.; Ahghari, P. Administration of hydrogen sulfide protects ischemia reperfusion-induced acute kidney injury by reducing the oxidative stress. Ir. J. Med. Sci. 2015, doi:10.1007/s11845-015-1328-z.

107. Dai, H.-B.; Ji, X.; Zhu, S.-H.; Hu, Y.-M.; Zhang, L.-D.; Miao, X.-L.; Ma, R.-M.; Duan, M.-L.; Li, W.-Y. Hydrogen sulphide and mild hypothermia activate the CREB signaling pathway and prevent ischemia-reperfusion injury. BMC Anesthesiol. 2015, 15, 119, doi:10.1186/s12871-015-0097-6.

108. Yu, Q.; Lu, Z.; Tao, L.; Yang, L.; Guo, Y.; Yang, Y.; Sun, X.; Ding, Q. ROS-Dependent Neuroprotective Effects of NaHS in Ischemia Brain Injury Involves the PARP/AIF Pathway. Cell. Physiol. Biochem. 2015, 36, 1539-1551.

109. Pope, M.R.; Bukovnik, U.; Tomich, J.M.; Fleming, S.D. Small $\beta 2$-glycoprotein I peptides protect from intestinal ischemia reperfusion injury. J. Immunol. 2012, 189, 5047-5056.

110. Liu, H.; Bai, X.-B.; Shi, S.; Cao, Y.-X. Hydrogen sulfide protects from intestinal ischaemia-reperfusion injury in rats. J. Pharm. Pharmacol. 2009, 61, 207-212.

111. Parks, D.A.; Bulkley, G.B.; Granger, D.N.; Hamilton, S.R.; McCord, J.M. Ischemic injury in the cat small intestine: Role of superoxide radicals. Gastroenterology 1982, 82, 9-15.

112. Schoenberg, M.H.; Fredholm, B.B.; Haglund, U.; Jung, H.; Sellin, D.; Younes, M.; Schildberg, F.W. Studies on the oxygen radical mechanism involved in the small intestinal reperfusion damage. Acta Physiol. Scand. 1985, 124, 581-589.

113. Younes, M.; Mohr, A.; Schoenberg, M.H.; Schildberg, F.W. Inhibition of lipid peroxidation by superoxide dismutase following regional intestinal ischemia and reperfusion. Res. Exp. Med. 1987, 187, 9-17.

114. Pan, H.; Chen, D.; Liu, B.; Xie, X.; Zhang, J.; Yang, G. Effects of sodium hydrosulfide on intestinal mucosal injury in a rat model of cardiac arrest and cardiopulmonary resuscitation. Life Sci. 2013, 93, 24-29.

115. Henderson, P.W.; Weinstein, A.L.; Sung, J.; Singh, S.P.; Nagineni, V.; Spector, J.A. Hydrogen sulfide attenuates ischemia-reperfusion injury in in vitro and in vivo models of intestine free tissue transfer. Plast. Reconstr. Surg. 2010, 125, 1670-1978.

116. Liu, Y.; Kalogeris, T.; Wang, M.; Zuidema, M.Y.; Wang, Q.; Dai, H.; Davis, M.J.; Hill, M.A.; Korthuis, R.J. Hydrogen sulfide preconditioning or neutrophil depletion attenuates 
ischemia-reperfusion-induced mitochondrial dysfunction in rat small intestine. Am. J. Physiol. Gastrointest. Liver Physiol. 2012, 302, G44-G54.

117. Yusof, M.; Kamada, K.; Kalogeris, T.; Gaskin, F.S.; Korthuis, R.J. Hydrogen sulfide triggers late-phase preconditioning in postischemic small intestine by an NO- and p38 MAPK-dependent mechanism. Am. J. Physiol. Heart Circ. Physiol. 2009, 296, H868-H876.

118. Wu, D.; Wang, J.; Li, H.; Xue, M.; Ji, A.; Li, Y. Role of hydrogen sulfide in ischemia-reperfusion injury. Oxid. Med. Cell. Longev. 2015, 2015, 1-16.

119. Ferlito, M.; Wang, Q.; Fulton, W.B.; Colombani, P.M.; Marchionni, L.; Fox-Talbot, K.; Paolocci, N.; Steenbergen, C. Hydrogen sulfide [corrected] increases survival during sepsis: protective effect of CHOP inhibition. J. Immunol. 2014, 192, 1806-1814.

120. Zhang, H.; Zhi, L.; Moore, P.K.; Bhatia, M. Role of hydrogen sulfide in cecal ligation and puncture-induced sepsis in the mouse. Am. J. Physiol. Lung Cell. Mol. Physiol. 2006, 290, L1193-L1201.

121. Zhang, H.; Zhi, L.; Moochhala, S.; Moore, P.K.; Bhatia, M. Hydrogen sulfide acts as an inflammatory mediator in cecal ligation and puncture-induced sepsis in mice by upregulating the production of cytokines and chemokines via NF-kB. Am. J. Physiol. Lung Cell. Mol. Physiol. 2007, 292, L960-L971.

122. Zhang, H.; Moochhala, S.M.; Bhatia, M. Endogenous hydrogen sulfide regulates inflammatory response by activating the erk pathway in polymicrobial sepsis. J. Immunol. 2008, 181, 4320-4331.

123. Zhi, L.; Ang, A.D.; Zhang, H.; Moore, P.K.; Bhatia, M. Hydrogen sulfide induces the synthesis of proinflammatory cytokines in human monocyte cell line U937 via the ERK-NF-kappa B pathway. J. Leukoc. Biol. 2007, 81, 1322-1332.

124. Li, L.; Salto-Tellez, M.; Tan, C.-H.; Whiteman, M.; Moore, P.K. GYY4137, a novel hydrogen sulfide-releasing molecule, protects against endotoxic shock in the rat. Free Radic. Biol. Med. 2009, 47, 103-113.

125. Wu, Z.; Peng, H.; Du, Q.; Lin, W.; Liu, Y. GYY4137, a hydrogen sulfide-releasing molecule, inhibits the inflammatory response by suppressing the activation of nuclear factor-kappa $\mathrm{B}$ and mitogen-activated protein kinases in Coxsackie virus B3-infected rat cardiomyocytes. Mol. Med. Rep. 2014, 11, 1837-1844.

126. Liu, Z.; Han, Y.; Li, L.; Lu, H.; Meng, G.; Li, X.; Shirhan, M.; Peh, M.T.; Xie, L.; Zhou, S.; et al. The hydrogen sulfide donor, GYY4137, exhibits anti-atherosclerotic activity in high fat fed apolipoprotein E(-/-) mice. Br. J. Pharmacol. 2013, 169, 1795-1809.

127. Li, L.; Fox, B.; Keeble, J.; Salto-Tellez, M.; Winyard, P.G.; Wood, M.E.; Moore, P.K.; Whiteman, M. The complex effects of the slow-releasing hydrogen sulfide donor GYY4137 in a model of acute joint inflammation and in human cartilage cells. J. Cell. Mol. Med. 2013, 17, 365-376.

128. Whiteman, M.; Li, L.; Rose, P.; Tan, C.-H.; Parkinson, D.B.; Moore, P.K. The Effect of Hydrogen Sulfide Donors on Lipopolysaccharide-Induced Formation of Inflammatory Mediators in Macrophages Antioxid. Redox Signal. 2010, 12, 1147-1154.

129. Chen, S.-W.; Zhu, J.; Zuo, S.; Zhang, J.-L.; Chen, Z.-Y.; Chen, G.-W. Wang, X.; Pan, Y.-S.; Liu, Y.-C.; Wang, P.-Y. Protective effect of hydrogen sulfide on TNF- $\alpha$ and IFN- $\gamma$-induced injury of intestinal epithelial barrier function in Caco-2 monolayers. Inflamm. Res. 2015, 64, 789-797. 
130. Guo, C.; Liang, F.; Masood, W.S.; Yan, X. Hydrogen sulfide protected gastric epithelial cell from ischemia/reperfusion injury by Keap1 S-sulfhydration, MAPK dependent anti-apoptosis and NF-кB dependent anti-inflammation pathway. Eur. J. Pharmacol. 2014, 725, 70-78.

131. Flannigan, K.L.; Agbor, T.A.; Blackler, R.W.; Kim, J.J.; Khan, W.I.; Verdu, E.F.; Ferraz, J.G.; Wallace, J.L. Impaired hydrogen sulfide synthesis and IL-10 signaling underlie hyperhomocysteinemia-associated exacerbation of colitis. Proc. Natl. Acad. Sci. USA 2014, 111, 13559-13564.

132. Hirata, I.; Naito, Y.; Takagi, T.; Mizushima, K.; Suzuki, T.; Omatsu, T.; Handa, O.; Ichikawa, H.; Ueda, H.; Yoshikawa, T. Endogenous hydrogen sulfide is an anti-inflammatory molecule in dextran sodium sulfate-induced colitis in mice. Dig. Dis. Sci. 2011, 56, 1379-1386.

133. Wallace, J.L.; Vong, L.; McKnight, W.; Dicay, M.; Martin, G.R. Endogenous and exogenous hydrogen sulfide promotes resolution of colitis in rats. Gastroenterology 2009, 137, 569-578.

134. Fiorucci, S.; Orlandi, S.; Mencarelli, A.; Caliendo, G.; Santagada, V.; Distrutti, E.; Santucci, L.; Cirino, G.; Wallace, J.L. Enhanced activity of a hydrogen sulphide-releasing derivative of mesalamine (ATB-429) in a mouse model of colitis. Br. J. Pharmacol. 2007, 150, 996-1002.

135. Flannigan, K.L.; Agbor, T.A.; Motta, J.-P.; Ferraz, J.G.; Wang, R.; Buret, A.G.; Wallace, J.L. Proresolution effects of hydrogen sulfide during colitis are mediated through hypoxia-inducible factor-1 $\alpha$. FASEB J. 2015, 29, 1591-1602.

136. Motta, J.-P.; Flannigan, K.L.; Agbor, T.A.; Beatty, J.K.; Blackler, R.W.; Workentine, M.L.; da Silva, G.J.; Wang, R.; Buret, A.G.; Wallace, J.L. Hydrogen sulfide protects from colitis and restores intestinal microbiota biofilm and mucus production. Inflamm. Bowel Dis. 2015, 21, 1006-1017.

137. Zanardo, R.C.; Brancaleone, V.; Distrutti, E.; Fiorucci, S.; Cirino, G.; Wallace, J.L. Hydrogen sulfide is an endogenous modulator of leukocyte-mediated inflammation. FASEB J. 2006, 20, 2118-2120.

138. Mariggiò, M.A.; Minunno, V.; Riccardi, S.; Santacroce, R.; de Rinaldis, P.; Fumarulo, R. Sulfide enhancement of PMN apoptosis. Immunopharmacol. Immunotoxicol. 1998, 20, 399-408.

139. Dufton, N.; Natividad, J.; Verdu, E.F.; Wallace, J.L. Hydrogen sulfide and resolution of acute inflammation: A comparative study utilizing a novel fluorescent probe. Sci. Rep. 2012, 2, 499, doi:10.1038/srep00499.

140. Blackler, R.W.; Motta, J.-P.; Manko, A.; Workentine, M.; Bercik, P.; Surette, M.G.; Wallace, J.L. Hydrogen sulphide protects against NSAID-enteropathy through modulation of bile and the microbiota. Br. J. Pharmacol. 2015, 172, 992-1004.

141. Wallace, J.L.; Devchand, P.R. Emerging roles for cyclooxygenase-2 in gastrointestinal mucosal defense. Br. J. Pharmacol. 2005, 145, 275-282.

142. Brancaleone, V.; Mitidieri, E.; Flower, R.J.; Cirino, G.; Perretti, M. Annexin A1 mediates hydrogen sulfide properties in the control of inflammation. J. Pharmacol. Exp. Ther. 2014, 351, 96-104.

143. Wallace, J.L.; Dicay, M.; McKnight, W.; Martin, G.R. Hydrogen sulfide enhances ulcer healing in rats. FASEB J. 2007, 21, 4070-4076.

144. Mard, S.A.; Ashabi, A.; Badavi, M.; Dianat, M. Protective effects of vitamin B6 alone and in combination with L-cysteine and NaHS on ethanol and indomethacin-induced gastric lesions in mice. Iran. J. Basic Med. Sci. 2015, 18, 253-258. 
145. Medeiros, J.V.; Bezerra, V.H.; Gomes, A.S.; Barbosa, A.L; Lima-Júnior, R.C.; Soares, P.M.; Brito, G.A.; Ribeiro, R.A.; Cunha, F.Q.; Souza, M.H. Hydrogen sulfide prevents ethanol-induced gastric damage in mice: role of ATP-sensitive potassium channels and capsaicin-sensitive primary afferent neurons. J. Pharmacol. Exp. Ther. 2009, 330, 764-770.

146. Chávez-Piña, A.E.; Tapia-Alvarez, G.R.; Navarrete, A. Inhibition of endogenous hydrogen sulfide synthesis by PAG protects against ethanol-induced gastric damage in the rat. Eur. J. Pharmacol. 2010, 630, 131-136.

147. Kimura, Y.; Kimura, H. Hydrogen sulfide protects neurons from oxidative stress. FASEB $J$. 2004, 18, 1165-1167.

148. Mard, S.A.; Neisi, N.; Solgi, G.; Hassanpour, M.; Darbor, M.; Maleki, M. Gastroprotective effect of NaHS against mucosal lesions induced by ischemia-reperfusion injury in rat. Dig. Dis. Sci. 2012, 57, 1496-1503.

149. Cui, J.; Liu, L.; Zou, J.; Qiao, W.; Liu, H.; Qi, Y.; Yan, C. Protective effect of endogenous hydrogen sulfide against oxidative stress in gastric ischemia-reperfusion injury. Exp. Ther. Med. 2013, 5, 689-694.

150. Flannigan, K.L.; Ferraz, J.G.; Wang, R.; Wallace, J.L. Enhanced synthesis and diminished degradation of hydrogen sulfide in experimental colitis: A site-specific, pro-resolution mechanism. PLoS ONE 2013, 8, doi:10.1371/journal.pone.0071962.

151. Lou, L.-X.; Geng, B.; Du, J.-B.; Tang, C.-S. Hydrogen sulphide-induced hypothermia attenuates stress-related ulceration in rats. Clin. Exp. Pharmacol. Physiol. 2008, 35, 223-228.

152. Jiang, B.; Tang, G.; Cao, K.; Wu, L.; Wang, R. Molecular mechanism for H(2)S-induced activation of K(ATP) channels. Antioxid. Redox Signal. 2010, 12, 1167-1178.

153. Liu, L.; Cui, J.; Song, C.-J.; Bian, J.-S.; Sparatore, A.; Del Soldato, P.; Wang, X.-Y.; Yan, C.-D. $\mathrm{H}(2)$ S-releasing aspirin protects against aspirin-induced gastric injury via reducing oxidative stress. PLoS ONE 2012, 7, doi:10.1371/journal.pone.0046301.

154. Fiorucci, S.; Antonelli, E.; Distrutti, E.; Rizzo, G.; Mencarelli, A.; Orlandi, S.; Zanardo, R.; Renga, B.; Di Sante, M.; Morelli, A.; et al. Inhibition of hydrogen sulfide generation contributes to gastric injury caused by anti-inflammatory nonsteroidal drugs. Gastroenterology 2005, 129, 1210-1224.

155. Mustafa, A.K.; Gadalla, M.M.; Sen, N.; Kim, S.; Mu, W.; Gazi, S.K.; Barrow, R.K.; Yang, G.; Wang, R.; Snyder, S.H. $\mathrm{H}_{2} \mathrm{~S}$ signals through protein S-sulfhydration. Sci. Signal. 2009, 2, doi:10.1126/scisignal.2000464.

156. Gil, V.; Gallego, D.; Jiménez, M. Effects of inhibitors of hydrogen sulphide synthesis on rat colonic motility. Br. J. Pharmacol. 2011, 164, 485-498.

157. Nagao, M.; Duenes, J.A.; Sarr, M.G. Role of hydrogen sulfide as a gasotransmitter in modulating contractile activity of circular muscle of rat jejunum. J. Gastrointest. Surg. 2012, 16, 334-343.

158. Kasparek, M.S.; Linden, D.R.; Farrugia, G.; Sarr, M.G. Hydrogen sulfide modulates contractile function in rat jejunum. J. Surg. Res. 2012, 175, 234-242.

159. Gallego, D.; Clavé, P.; Donovan, J.; Rahmati, R.; Grundy, D.; Jiménez, M.; Beyak, M.J. The gaseous mediator, hydrogen sulphide, inhibits in vitro motor patterns in the human, rat and mouse colon and jejunum. Neurogastroenterol. Motil. 2008, 20, 1306-1316. 
160. Gil, V.; Parsons, S.; Gallego, D.; Huizinga, J.; Jimenez, M. Effects of hydrogen sulphide on motility patterns in the rat colon. Br. J. Pharmacol. 2013, 169, 34-50.

161. Shafigullin, M.Y.; Zefirov, R.A.; Sabirullina, G.I.; Zefirov, A.L.; Sitdikova, G.F. Effects of a hydrogen sulfide donor on spontaneous contractile activity of rat stomach and jejunum. Bull. Exp. Biol. Med. 2014, 157, 302-306.

162. Tang, G.; Wu, L.; Wang, R. Interaction of hydrogen sulfide with ion channels. Clin. Exp. Pharmacol. Physiol. 2010, 37, 753-763.

163. Teague, B.; Asiedu, S.; Moore, P.K. The smooth muscle relaxant effect of hydrogen sulphide in vitro: Evidence for a physiological role to control intestinal contractility. Br. J. Pharmacol. 2002, 137, 139-145.

164. Quan, X.; Luo, H.; Liu, Y.; Xia, H.; Chen, W.; Tang, Q. Hydrogen sulfide regulates the colonic motility by inhibiting both L-type calcium channels and BKCa channels in smooth muscle cells of rat colon. PLoS ONE 2015, 10, doi:10.1371/journal.pone.0121331.

165. Martinez-Cutillas, M.; Gil, V.; Mañé, N.; Clavé, P.; Gallego, D.; Martin, M.T.; Jimenez, M. Potential role of the gaseous mediator hydrogen sulphide $\left(\mathrm{H}_{2} \mathrm{~S}\right)$ in inhibition of human colonic contractility. Pharmacol. Res. 2015, 93, 52-63.

166. Yamane, S.; Kanno, T.; Nakamura, H.; Fujino, H.; Murayama, T. Hydrogen sulfide-mediated regulation of contractility in the mouse ileum with electrical stimulation: roles of L-cysteine, cystathionine $\beta$-synthase, and $\mathrm{K}^{+}$channels. Eur. J. Pharmacol. 2014, 740, 112-120.

167. Yamane, S.; Nomura, R.; Yanagihara, M.; Nakamura, H.; Fujino, H.; Matsumoto, K.; Horie, S.; Murayama, T. L-cysteine/D,L-homocysteine-regulated ileum motility via system $\mathrm{L}$ and $\mathrm{B}^{\circ,+}$ transporter: Modification by inhibitors of hydrogen sulfide synthesis and dietary treatments. Eur. J. Pharmacol. 2015, 764, 471-479.

168. Lu, W.; Li, J.; Gong, L.; Xu, X.; Han, T.; Ye, Y.; Che, T.; Luo, Y.; Li, J.; Zhan, R.; et al. H2 S modulates duodenal motility in male rats via activating TRPV1 and K(ATP) channels. Br. J. Pharmacol. 2014, 171, 1534-1550.

169. Patacchini, R.; Santicioli, P.; Giuliani, S.; Maggi, C.A. Pharmacological investigation of hydrogen sulfide $\left(\mathrm{H}_{2} \mathrm{~S}\right)$ contractile activity in rat detrusor muscle. Eur. J. Pharmacol. 2005, 509, 171-177.

170. Trevisani, M.; Patacchini, R.; Nicoletti, P.; Gatti, R.; Gazzieri, D.; Lissi, N.; Zagli, G.; Creminon, C.; Geppetti, P.; Harrison, S. Hydrogen sulfide causes vanilloid receptor 1-mediated neurogenic inflammation in the airways. Br. J. Pharmacol. 2005, 145, 1123-1131.

171. Chattopadhyay, M.; Kodela, R.; Nath, N.; Dastagirzada, Y.M.; Velázquez-Martínez, C.A.; Boring, D.; Kashfi, K. Hydrogen sulfide-releasing NSAIDs inhibit the growth of human cancer cells: A general property and evidence of a tissue type-independent effect. Biochem. Pharmacol. 2012, 83, 715-722.

172. Wallace, J.L.; Caliendo, G.; Santagada, V.; Cirino, G. Markedly reduced toxicity of a hydrogen sulphide-releasing derivative of naproxen (ATB-346). Br. J. Pharmacol. 2010, 159, 1236-1246.

(C) 2015 by the authors; licensee MDPI, Basel, Switzerland. This article is an open access article distributed under the terms and conditions of the Creative Commons Attribution license (http://creativecommons.org/licenses/by/4.0/). 